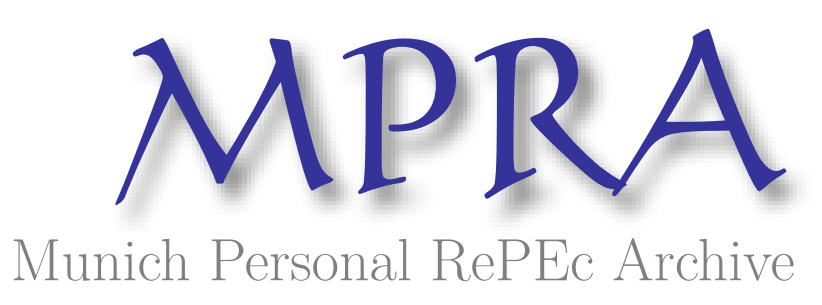

\title{
Corruption as a legacy of the medieval university: Financial affairs
}

Osipian, Ararat

1 May 2004

Online at https://mpra.ub.uni-muenchen.de/8472/

MPRA Paper No. 8472, posted 26 Apr 2008 02:18 UTC 


\title{
CORRUPTION AS A LEGACY OF THE MEDIEVAL UNIVERSITY: FINANCIAL AFFAIRS ${ }^{*}$
}

\author{
Ararat L. Osipian ${ }^{\dagger}$ \\ ararat.osipian@vanderbilt.edu \\ araratos@yahoo.com \\ Dept. of Leadership, Policy, and Organizations \\ Vanderbilt University \\ Peabody \#514 \\ 230 Appleton Place \\ Nashville, TN 37203-5721 \\ Ph: (615)322-8000 \\ Fax: (615)3432391 \\ Correspondence: \\ Osipian A. \\ 3105 Bellwood st, apt $\mathrm{H}$ \\ Nashville, TN, 37203, USA
}

Nashville, TN - 2004

* This is the full version of the paper presented at the Annual Conference of the Association for the Study of Higher Education (ASHE), Kansas City, MO, November 2004.

$\dagger$ Ararat L. Osipian is a Ph.D. candidate in the Department of Leadership, Policy and Organizations at Peabody College of Education at Vanderbilt University, USA 
Looking back upon the centuries one would suspect that in earlier ages universities of medieval France and Italy were very different from the multiplicity of organizational and institutional forms of higher education institutions in modern times, and yet one would be surprised how much these old universitas and modern universities have in common. One of the common features may be corruption and academic misconduct that can often bee seen in universities. The increasing scale and scope of corruption in higher education in the former Soviet Bloc as well as numerous other countries urges a better understanding of the problem within the context of socio-economic transformations. Corruption in higher education is deeply rooted in the organizational structure of each higher education institution. Corruption has a long history and a proud tradition. Corruption in higher education is an organic part of corruption overall, with its culture, traditions, functions, and mechanisms. The goal of this paper is to present a description of modern day higher education corruption from a historical perspective. This paper is based on the techniques of positive analysis along with some elements of comparative analysis, and withstands from normative or moral judgments. A well-structured description of higher education corruption in a historical context is helpful in developing strategies for its eradication or prevention. This paper first presents the concept of corruption as a historical category and then analyzes corrupt legacies at the stages of admission, teaching and learning, and graduation. It also addresses issues of funding, discrimination against foreign nationals, publishing, and state-university relations. The genesis of forms of corruption and the determination of corruption as such is understood in a changing historical context.

Key words: corruption, medieval, misconduct, university 


\section{CONTENT}

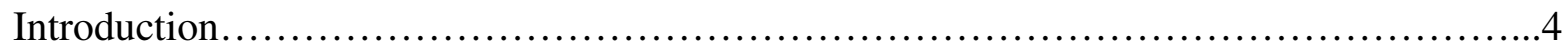

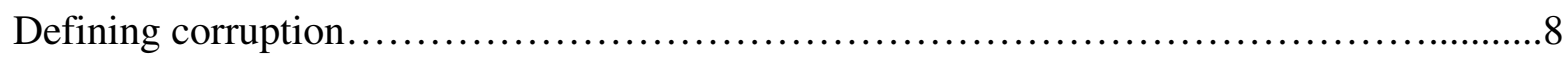

Visible and essential legacies of medieval universities...........................................12

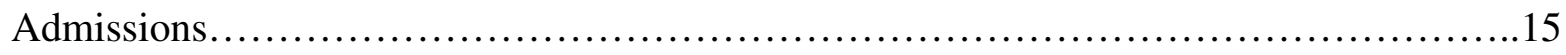

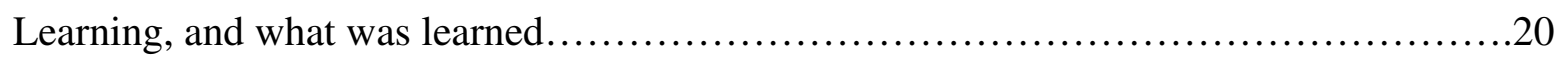

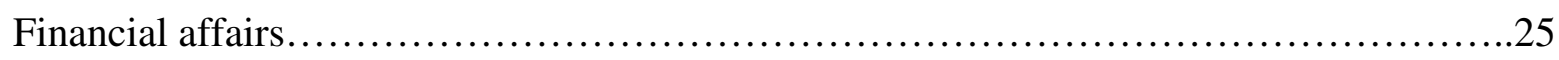

Misconduct and informal relations....................................................

Graduation and academic degrees................................................... 37

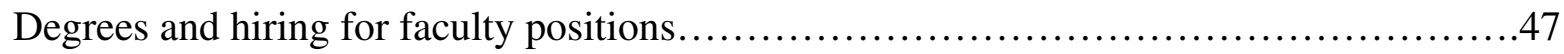

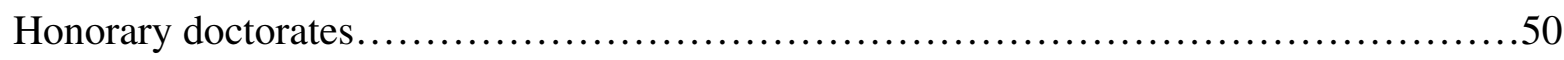

Nationalism, internationals, and discrimination........................................54

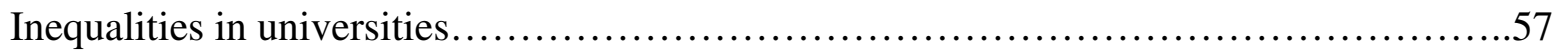

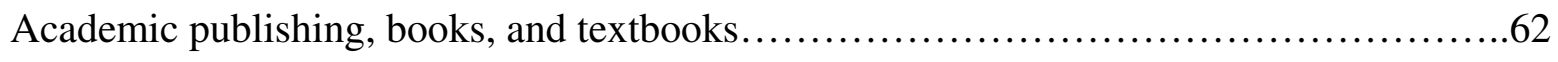

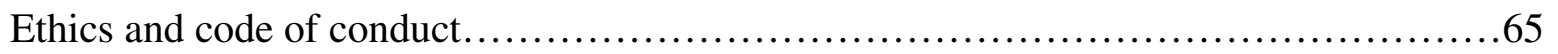

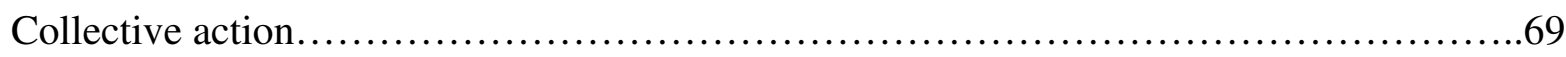

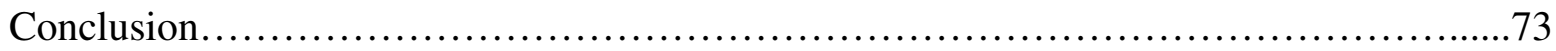

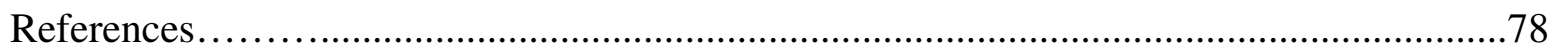




\section{INTRODUCTION}

Factors that reshape higher education in the former Soviet Union (FSU) are common for all countries. These are growing demand for higher education, globalization, and government inefficiency. Countries of the former Soviet Bloc reform higher education faster than most of the European countries. Political, economic, ideological, language, and cultural factors are all important for the reform. One of the negative sides of the reform is growing corruption of higher education institutions and educational industry overall. Corruption, and higher education corruption in particular, is something known but not described theoretically. At the same time, an increasing scale and scope of corruption in higher education in the former Soviet Bloc as well as numerous other countries urges better understanding of the problem within the context of socioeconomic transformations. Corruption in higher education is deeply rooted into the organizational structure of each higher education institution. Corruption has a long history and a proud tradition. Corruption in higher education is an organic part of corruption overall, with its culture, traditions, functions, and mechanisms.

The goal of this paper is to present a description of the higher education corruption in historical as well as comparative perspective. It may be used as a building block in an attempt to develop a positivist theory of corruption. This paper is based on the techniques of positive and comparative analysis. Few normative comments or suggestions may also be offered in this paper. Normative analysis, however, is not a major tool in this research. Numerous historical analogies are used to better understand the issue of education corruption. Well-structured description of higher education corruption in historical context may be helpful in developing strategies for its reduction, eradication or prevention. 
Corruption is present to a larger or lesser extent in any society at any stage of its development. Historically, fundamental changes in the societies lead to the phenomenal splash in corruption, as a part of illegal activities. These illegal activities, however, later became legal. Hence, what was regarded as corrupt earlier was then regarded as something normal. Adversely, what was earlier accepted as a norm and well-tolerated by the society may well become an unacceptable practice of corruption. In many societies or types of organizations, corruption is an indivisible part of their steady state. Highly institutionalized corruption is normally present in the societies where corruption is widespread and has a large scale. An institutionalized corruption in such cases plays the role of substitute for the legal institutions or it may be complementary to them.

Within the fundamental economic and social transformations, a phenomenal growth of corruption does not necessarily lead to its institutionalization. Even widespread corruption may long stay un-institutionalized. Such long-term chaotic condition may be explained in part by preventive measures, undertaken by the public or by the state. The time differences, with which societies or groups reach certain level of institutionalization of corruption, are explained by the preliminary conditions and ethic and cultural aspects of the society. Consistent with expectations, historical aspect of corruption may be found to be as important as its structural basis.

This paper is structured based on the idea of comparisons between functions and practices of medieval universities and universities in the FSU. The FSU is taken as a good example but in no way it should be understood as an exception. Well-exposed and often rampant corruption in the fast-growing higher education sector is valuable for its convenience in studying corruption through simple comparisons. Some related features of US universities are also highlighted in this paper. 
This paper draws extensively on the works of Brockliss, Compayre, Haskins, Hill, Hyde, Kaminsky, Key, Kibre, Maieru, Piltz, Rait, Rashdall, Thelin, and Verger, devoted to medieval universities. Time limits, as an immanent part of an historical analysis, will capture universities in two periods: universities of the Middle Ages, approximately from 1100 till 1500, and then universities of late Soviet and post-soviet period from 1970s till present.

One way of investigating higher education corruption in an historical perspective would be to follow along the line of emergence, creation, and development of the university system from early medieval ages till present, i.e. presenting genesis of the university. This paper uses somewhat different way of exploring the issue. It uses method of historical analogies and considers object of the research, i.e. university, in its static and not in dynamics. One of the reasons of choosing this way is that presenting a complete picture of the university genesis would be to cumbersome and any attempt to stress the material would lead to the loss of certain essential features, specifics, or details. Such a loss routinely occurs in works of comparative economic history. More importantly, it is difficult to follow the development of university features through the ages due to substantial breaks in the process of development and change of forms that prevents from establishing causality and clear cause-sequence relations.

Method of historical analogies allows working in two directions. First, this paper reconstructs major features of medieval universities and projects them on certain features of modern universities, which are regarded as corrupt. The second direction anticipates exploration of corrupt practices that take place in modern universities and search for analogous forms of behavior or misconduct in medieval universities. This approach allows operating within the limits of the principle of unity of the historical and the logical, while sacrificing continuity in the history of university development. 
This paper first presents the concept of corruption as a historical category. Genesis of forms of corruption and determination of corruption as such is understood in a changing historical context. Legacies of medieval universities are often visual, well-exposed, and even artificially reproduced for their inspiration, while sometimes these legacies are invisible but essential to the universities. Main body of this paper is built along the academic process and include issues of admissions, learning, financial affairs, misconduct and informal relations between faculty and students, reasons for these informal relations, graduation and conferring the degrees, hiring of faculty members by universities, conferring honorary doctorates, and role of doctorates then and now. This paper also includes some comparative analysis of corruption in such areas, as nationalism, internationalism, and discrimination; inequalities and disparities in income and lifestyles; and publishing and distribution of books. Professional ethics, code of conduct, and collective action are presented as possible forms of tackling misconduct and corruption in universities. Conclusion summarizes and generalizes the findings. 


\section{Defining corruption}

Corruption is something difficult to define. As Keller points out:

The word "corruption" itself, as the numerous definitions attached to it in the Oxford English Dictionary attest, is an elusive and ambiguous one. For some it is a strongly normative concept, describing an illegal or immoral transgression of prevailing mores for the benefit of oneself or one's group. In this sense the presence of corruption usually is as much dependent upon the stance of the observer as it is on the act of the transgressor: I am reality-oriented; you are self-interested; he is corrupt. Often the corrupt do not regard themselves as such; and rightly so, by their own frame of values. Often enough (as in tyrannies) the most corrupt act is to accord with law and custom; to violate or subvert authority may well be the higher morality. Nor is corruption, even when accepted as such, necessarily harmful. No less than reform, as Samuel Hantington observed, it "may... be functional to the maintenance of a political system. Corruption has been understood in yet another sense: as something natural, organic, an ineluctable part of the business of living." (Keller, 1978, p. 7)

The definition of corruption varies depending on the inquiring discipline. Whatever problem economists might have in explaining corruption is indicated by Rose-Ackerman's (1978) definition of corruption as an "allocative mechanism" for scarce resources. Johnston says that not all behavior that breaks rules is corruption: "Corruption involves abuse of a public role or trust for the sake of some private benefit." (Johnston, 1982, p. 4)

Peters and Welch analyze corrupt acts by the component elements involved in the corrupt act and exchange: "We believe this process can meaningfully be partitioned into the "public official" involved, the actual "favor" provided by the public official, the "payoff" gained by the 
public official, and the "donor" of the payoff and/or "recipient" of the "favor" act." (Peters and Welch, 1978, p. 976) Johnston summarizes the definitional problem: "We should not expect to find a sharp distinction between corruption and no corrupt actions. Instead, we will find fine gradations of judgment, reflecting a variety of equivocations, mitigating circumstances, and attributed motives." (Johnston, 1986, p. 379) Berg, Hahn, and Schmidhauser state that the definition of corruption requires a systemic concept. They write that "Political corruption violates and undermines the norms of the system of public order which is deemed indispensable for the maintenance of political democracy.” (Berg, Hahn, and Schmidhauser, 1976, p. 3)

The definition most cited in the political literature is given by Nye:

Corruption is behavior which deviates from the normal duties of a public role because of private-regarding (family, close private clique), pecuniary or status gains, or violates rules against the exercise of certain types of private-regarding influence. This includes such behavior as bribery (use of reward to pervert the judgment of a person in a position of trust); nepotism (bestowal of patronage by reasons of ascriptive relationship rather than merit); and misappropriation (illegal appropriation of public resources for privateregarding use) (Nye, 1967, p. 419).

Lasswell and Rogow propose that "A corrupt act violates responsibility toward at least one system of public or civic order and is in fact incompatible with (destructive of) any such system. A system of public or civic order exalts common interest over special interest; violations of the common interest for special advantage are corrupt." (Lasswell and Rogow, 1963, p. 320) Leon contends that "political corruption is a cooperative form of unsanctioned, usually condemned policy influence for some type of significant personal gain, in which the currency could be economic, social, political, or ideological remuneration", and concludes that political 
corruption is an integrated, systemic part of the American political process (Leon, 1993, p. 25). The same suggestion could probably be made of the system of higher education in the FSU. Key defines graft “... as an abuse of power for personal or party profit.” (Key, 1934, p. 386) He says that graft usually involves a relationship between the official exercising the power which is abused and some other individual or individuals and that the techniques of graft are the methods employed in these relationships plus the methods used in cases of graft involving only a single individual (Key, 1934, pp. 386-387).

In the Post-Soviet literature, corruption is normally described in the area of the shadow economy and, to a lesser extent, in relations between the economy and different levels of state bureaucracy and administration, including political organizations. A newer trend in Russian and Ukrainian research on corruption is to present a descriptive analysis of perceptions of corruption held by the population. Such a descriptive analysis is based on the results of based on polls and surveys. By estimations, corruption in education in the Russian Federation alone is a multibillion industry. It was estimated that in 2003 parents paid 26.5 billion Russian Rubles in bribes toward the education of their children (Newsru, 2004). Higher education corruption is still not described theoretically.

This research asserts that the definition of corruption as the abuse of public office for private gain is convenient in the sense that it is perfectly inclusive. However, the word abuse can have numerous interpretations and contexts. One can take, for instance, child abuse and alcohol abuse. In these two cases the same word has two different meanings. More recent substitution of the word abuse by the word misuse does not change the insufficiency of the definition. The strength of the definition is in its inclusiveness, but the weakness of it is that it is not specific. 
The definition is very general and lack specificity. It is well applicable, but it does not discover the essence of corruption.

This research takes as a basis a different concept of corruption. This concept is based on the principle of historicism and can be formulated as the following: Corruption is a net or a system of relations, including property relations, that 1) exists between individuals and institutions that enter and maintain these relations on the basis of both voluntary and involuntary participation, 2) is based upon fundamental socio-economic conditions within specific institutional and time frames, 3) serves as a mechanism of distribution and redistribution of wealth and exercising power, 4) functions in regimes of decreased scale, simple, and increased reproduction, 5) violates current laws, norms, and formal procedures existing within a society, and 6) is either recognized or not recognized as such by different groups of people.

Corruption is a complex phenomenon that exists in multiple dimensions and is observed and not observed, tolerated and not tolerated, estimated and not, by different social and economic strata, i.e. it is visible and invisible, tolerable and intolerable, estimable and inestimable, measurable and un-measurable. The same events, actions, and relations that occur in different periods in different countries are treated as corrupt or not corrupt. The same personages placed in alternative socio-economic settings may be regarded as corrupt or otherwise. A landlord who charges merchants a reasonable fee for passing through his feud exercises his public authority and is not regarded as corrupt. A landlord who charges merchants for raising dust on his roads, or who erects a bridge on a flat place to charge an extra "bridge fee," imposed by the king, is regarded as corrupt, at least by the merchants. While in many countries of Africa and Asia draconian corruption is not only a legitimate form of existence of public officials of all levels and ranks, but is in fact a form of state governance, in Western Europe corruption is at least opposed 
and prosecuted. In transitional societies, the largest bribe traditionally goes to the official whose primary duty is to make sure that no corrupt activities take place. In this case, the "control over controllers" concept becomes of little use.

Medieval students in the University of Paris were encouraged and, moreover, granted a right by their principals to beg on the streets. This privilege in medieval cities was controlled and normally granted to monks. Today it may sound at least unordinary, but at that time it was entitlement rather than corruptness. The last example in support of the concept of the importance of historical context in defining corruption is the issue of celibacy. Celibacy was a requirement for all the masters and faculty in medieval universities (Rashdall, 1936 (c), p. 395). This is how Hill describes the first violation of this rule: "[Dell] was thus already a notorious radical when in May 1649 he was elected Master of Gonville and Caius College, Cambridge - the first married man to hold that position." (Hill, 1972, p. 120) By now the opposite would be strange, but at that time marriage itself could be considered as an inappropriate act of corruption.

\section{Visible and essential legacies of medieval universities}

Colleges and universities throughout the world depict and reflect different features of their medieval predecessors. Higher education institutions in different countries are characterized by certain clusters of features that they acquired directly and indirectly from universities of the Middle Ages. Some of these features are visible and some are not. Some of these features are essential even though they may not be visible, and some are rather artificial constructs, strongly visible but inessential. Thelin says that "Modern colleges and universities are fond of invoking the legacy of medieval universities in such forms as academic gowns, commencement processions, or the Gothic towers which fill hundreds of American campuses. Nostalgia, hardly 
an accurate sense of history, allows medieval splendor to be carried forward several centuries and combined with modern convenience." (Thelin, 1982, p. 25) Indeed, made-of-stone gothic campuses of Yale and Boston College remind us medieval castles, while red-brick campuses of Harvard and Vanderbilt strive to detect some degree of belonging to their medieval ancestors as well. Thelin notes: "The medieval university is attractive because it is inspirational. The colors, grandeur, and traditions revived in academic ceremonies are today's translations of the Middle Age's legacy. Belief and loyalty as elements of organizational saga, are tempting themes for linking the medieval university to the American campus." (Thelin, 1982, p. 25) Other places within the same country, i.e. Boston University, MIT, and vast majority of urban public colleges and universities, located in large metropolitan areas visibly do not have anything in common with universities of the Middle Ages.

There might be not a single university in the FSU that reminds medieval universities by its architecture. Cappas and gowns are also nonexistent in the former Soviet republics. Nevertheless, universities in different parts of the world have numerous common features. Some of these common features are essential, including general structure, requirements for the degrees, degrees themselves, hierarchy, and subordination. Other essentials, such as sources of funding, relations with the state, ways of governance, admission policies and enrollment, are distinct. As Haskins states:

And yet, great as these differences are, the fact remains that the university of the twenties century is the linear descendant of medieval Paris and Bologna. They are the rock whence we were hewn; the hole of the pit whence we were digged. The fundamental organization is the same, the historic continuity is unbroken. They created the university tradition of the modern world, that common tradition which belongs to all our institutions 
of higher learning the newest as well as the oldest, and which all college and university men should know and cherish (Haskins, 1957, pp. 2-3).

In US universities a diploma does not bear any information beside the name of the university, the degree, and signatures of university administrators. If lost, it can be replaced multiple times with a modest replacement fee. An individual can have several copies of the diploma. Transcript is a key document in the US. In the Soviet Union and later the FSU, a diploma is issued only once and, if lost, may be replaced by its duplicate, which clearly states that it is a duplicate and not the original diploma. A diploma bears whole range of information, including country, the degree, specialty, qualification(s), department, faculty (school), name of the higher education institution, seal of the institution, signatures of university administrators, year of entering the university and year of graduation, and unique number of the diploma. Often diploma is issued in two languages: Russian and language of the republic. Now Russian is often replaced by English. Universities also issue so-called international diplomas that contain all information in two languages: language of instruction and English, and include picture of the graduate. In all cases, a transcript is an addition to the diploma and is not valid without the diploma.

In the centralized systems of higher education, the government accepts the duty and responsibility to oversee the quality of higher education and exercises functions of supervision, accreditation, and control. In such systems universities are not inclined to advance their imaginable medieval legacies. In countries with decentralized systems and strong independent private sector, every school tries to expose or prove it's belonging to the deep historical traditions and culture of medieval universities as something of high inspirational value and devotion to the scholarship. Ironically, their medieval ancestors were not perfect examples of 
inspiration and scholarship. Thelin points out that "The logos, seals, and mottoes found on contemporary college diplomas are a rich inheritance from the medieval university, whose licenses asserted the standard of pro bono publico - "for the public good." (Thelin, 1982, p. 34) Each American institution gives a concise statement of its educational mission via its motto, many of which are in Latin. Often regalia serve as a compensation for low academic credibility of an institution. This trend of introducing traditions and academic insignia is now developing in many parts of the world, including the FSU and China.

It is essential that starting the early ages universities have complex internal and external politics. Higher education institutions are the scene of the struggle for the power and resources, where "... individuals or groups with different interests can go "on the Square" and interact by forming coalitions, bargaining, compromising, and reaching agreements that they believe to be to their advantage." (Birnbaum, 1988, p. 130) Higher education institutions are complexes where groups are specialized and heterogeneous in their interests and preferences. The corrupted environment of mutual distrusts and political intrigues is inherently unstable. This instability creates psychological pressure on those who participate in corruption and those who do not. The process of interaction in the political system, in which the power is negotiated, is slowly replaced by emerging new rules and norms. This new process is most beneficial for and promoted by the administrative bureaucracy. Professional bureaucracy loses its power in controlling the flow of bribes and so more professionals tend to occupy the key administrative positions.

\section{Admissions}

We will now consider the process of and requirements for admissions to a medieval university as a starting point in academic life. Belonging to the student body of a university 
anticipated certain privileges. At the same time, it was not considered a noble characteristic and did not guarantee wealthy life in a future. The process of admission to universities was quite loose and non-selective. Thelin writes that "The university was characterized by remarkable selfselection: accessible to those who sought inclusion in the circle of scholars and teachers, it had little appeal to other groups." (Thelin, 1982, p. 36) However, there were certain basic prerequisites for those who entered the school. These prerequisites were not imposed by the faculty. They were rather a set of skills necessary to proceed with the studies. These basic skills are described by Rashdall:

Before the student could profitably attend university lectures, he must have learned to read, write, and understand such Latin as was used in the schools. Latin, it must be remembered, was not merely the language of the ordinary lecture-room, but theoretically at least of ordinary student life. The freshman must have been able to talk some Latin as well as to understand it. There was not such thing as an entrance examination, except in the colleges; and the want of proper grounding in the Latin Language constituted one of the most glaring defects of the medieval system. Still, in the first half of our period, when the universities were cosmopolitan, conversational Latin must have been almost a necessity of life to the university student. Even students from the different provinces of the same country could hardly have understood each other without its aid; and in the later period we find Latin-speaking in college and hall strictly enforced by statute. A statute of Paris makes the ability of a petitioner to state his case before the rector in his bona-fide studentship. The certificate of 'scholarity' was to be refused if the applicant's Latinity proved unequal to the strain. So the founder of the chantry [college, auth.] which included provision for two scholars provides that one of them was to be sent to the 
university when he could 'read, sing, and construe well and compose twenty-four verses on one subject in one day' (Rashdall, 1936 (c), pp. 341-342).

Basic skills needed to pursue university education were not tested during the admission. As a result, many newly admitted students were not prepared for classes. Many of those who were prepared did not demonstrate accuracy and high attendance in the classes and so lost some of the qualifications they had prior to entering the university. Rashdal says that "It is probable that there was a residuum of men who understood even less of the lectures which they attended, or were supposed to attend, than an ignorant monk or 'hedge-priest' did of the psalter which he daily muttered. We have already seen that large numbers of students - probably a majority never proceeded even to the lowest degree; there was no compulsion (except in the colleges) to enter for any examinations whatever, and numbers must have left the university knowing little more than when they entered it." (Rashdall, 1936 (c), p. 343)

Today, in many parts of the world, academic records necessary to enter higher education are often falsified. Kigotho (2004) points out that academic fraud becomes a routine and supplies unprepared students to universities. Formalization of pre-tertiary academic achievements and abilities in transcripts, secondary school certificates, national tests, and international tests (TOEFL, GRE, etc) creates a strongest incentive for academic fraud. There are numerous investigated cases of professional GRE-takers who take the test instead of their clients. The clients then use high test scores to enter universities in the US, or to obtain the entry student visa. These cases may take place in China as well as in the US.

Admissions to higher education institutions in the Soviet Union and later the FSU differ radically from what was described in the medieval universities. The state provides full funding for students accepted to universities. It is prestigious and beneficial to be enrolled in a university, 
and guarantees future employment. Even now, when the state no longer guarantees job placements for college graduates, governmentally financed university places are a high stake. University faculty makes admission decisions based on the results of oral entry examinations. Oral examinations are subjective and admissions to universities are corrupt. The Russian Federation is now introducing the standardized computer-graded examination that will determine admission to universities. Naturally, faculty members oppose this reform.

Critics of the reform predict an increase in educational bureaucracy and transaction costs, necessary to administer the standardized examination. A compromise between the authorities and the faculty may be found. A certain number of publicly funded places may be distributed among the faculty to be reserved for their children. By analogy, in the US, many colleges guarantee significant or full tuition coverage for the children of their faculty independently from the college of their choice. Also, some of the leading universities in the Russian Federation preserve the right to continue selection based on the entry examinations.

It is important to distinguish between the form and the essence. Self-selection in both the medieval universities and their modern counterparts is not the same. Access, being the same in form, is in fact different in its essence. While in medieval Europe a university degree was not a guarantee for higher social position and even basic literacy was something very distant from nobility, today higher education provides a strong ground for social status and economic position. System of self-selection, even though an equilibrium, may not necessarily be the optimum. Continuity of self-selection based solely on the ability to pay for education leads to a diminished total social welfare in the long run. This creates a ground for considering admission decisions heavily dependent on family income as corrupt. 
In broader terms, all admission decisions based on non-academic criteria for selection may be corrupt. This includes promising athletes for income- and prestige-generating intramural sports, gifts and anonymous donations from the applicants' families, and applicants who are potential generous contributing alumni in the future. This leads to the distinction between corruptness of the essence of the system, i.e. of the system and the mechanism an institution operates, from corruptness of functioning of an institution. While admission in exchange for money in form of high tuition represents corruptness of the system, admission to the governmentally financed place in exchange for a bribe represents corruption of the function of selection.

To summarize, admissions to private universities on non-competitive basis in the FSU and in the US without the entry examinations or with an interview, which is rather a formality, appears to be a legacy of the medieval university. Self-selection is based solely on a student's ability and willingness to pay tuition and fees. In the US, this type of self-selection is taken as something normal, while in the FSU it is often referred to as a destructive trend, detrimental to the society and to the system of higher education. According to Soviet type proletarian logic, it is corrupt.

\section{Learning, and what was learned}

Degrees that are now conferred by universities throughout the world came to us from the medieval universities. In the Soviet higher education, however, bachelor and masters degrees were replaced by the five-year degree called "specialist." Now, as higher education in the republics of the FSU is turning to the Euro Model of higher education base don the principles of Bologna Declaration, the specialist degree is being slowly replaced with bachelor and master or 
magister degrees. Interestingly, well-established universities of the class of Moscow State University preserve their right to continue conferring five-year specialist degrees and ground this decision in the fact that they give fundamental knowledge to their students and so the degree is classical.

Content of an academic degree is, no doubt, more important than its name. Apparently, renaming the former Specialist degree into B.A., B.Sc., M.A., and M.Sc. will not lead to the equivalency of the degrees. Corrupt practices that undermine the quality of instruction and curriculum are now as real as they were in the Middle Ages. Description of the course of study for the Bachelor of Arts and Master of Arts in the medieval universities is presented by Thelin: "The bachelor of arts course apparently was an introduction into the scholars' guild. It took about one and a half years of reading and lectures, during which the student could not teach. At the deposition, a freshman hazing where the new student had to host a banquet for fellow students and masters, he had to swear to an oath of attendance and pay schooling fees. Afterward he received the gown called a cappa." (Thelin, 1982, p. 42)

Time to the degree is always considered an important indicator of the overall situation in the higher education sector in a specific socio-economic context. In the world of medieval learning, many students were not in a hurry or under pressure to complete their degrees. In the Soviet times and later in the FSU, most of students complete five-year programs in five years. This is considered a norm. In the US, the average time to the four-year Bachelor degree is equal to six years.

The Master of Arts course was longer and more important than the Bachelor of Arts curriculum. Thelin notes: "After having received the Bachelor of Arts degree, a student spent four to six years reading prescribed works and preparing for the inception - a formal, public 
disputation. Successful completion led to receipt of the license, in which the student marched in a solemn procession, knelt before the chancellor, and (once again) paid for the ever-popular academic banquet." (Thelin, 1982, p. 34) There were two forms of learning process present: lecture and disputation. Even though the degree requirements were well-written and formalized in the process of university development, these requirements and procedures were often loosely followed or violated. Engen states that "The statutes were never fully observed. It is difficult to discover what discrepancies existed in the thirteen century between the statutes and everyday life. But the curricula in practice were probably less rigid than foreseen.” (Engen, 2000, p. 15)

While in the US not only the degree is important, but the university that conferred this degree, in the Soviet and post-soviet systems all the degrees were and still are formally certified by the state. This equality of the degrees was quite consistent with their quality. Now, however, quality varies significantly. Many private higher education institutions and some public colleges and universities produce low quality specialists, abusing the system of state accreditation.

As it appears to be common in the medieval universities, students are now relaxed in attending the lectures and seminars. System of free attendance of lectures has been introduced in some of the Soviet higher education institutions in 1990. Many ironically referred to it as a system of "free non-attendance." Students rather look for exceptions in their favour than follow the rules. Spring is always a good time to remind students of their duties.

Student and teacher misconduct in regard of examinations as well as punitive measures are described by Thelin as follows:

According to documents and memoirs, a student's initiation into scholarly ranks required masterity of specified readings, attendance at lectures, and the swearing of an oath. Accurate reconstruction of the pattern calls at a rule's intent and enforcement, as well as 
its formal statement. Although fragrant bribery and deceit were punished severely, evidence shows that a student could partially ease the crisis of examinations by holding a banquet for his masters. Within the university, penalties for rule breaking often rewarded the academic community. The statutes of the Sorbonne, for example, decreed that a fellow who attacked a servant must pay one sester, or four gallons of good wine - not to the injured servant, but to his own fellows. This fine was comparable to that levied on a student caught speaking French instead of Latin in the hall or arriving late for dinner (Thelin, 1982, p. 34).

Some universities in the FSU use fines as penalties for not meeting the deadlines of the term papers, midterms, final examinations, etc. Most of these universities are private for profit, but some public institutions do it as well. Revenue from the fines is directed to the university budget. Students oppose such practices and say that universities make extra money from the fines. Many consider such practice as corrupt. This may be interpreted as a classical Red Tape scheme, where the authorities first impose certain restrictions and then charge their clients for violating the restrictions (Guriev, 2003). In many cases existence of such fines is used by the faculty members as a basis for corruption in form of extortions. Students can pay certain amount of money directly to their professor instead of paying fines to the college administration.

Universities in the US often use practice of cover-up as related to their students. They employ substantial police staff not only to provide security on campus, but also to fence their students from having to deal with metropolitan police in case of minor violations, such as underage drinking, driving under intoxication, etc. This is especially common in expensive private colleges. 
Medieval universities imposed some of the restrictions or regulations on student conduct and activities, but did not control most of the student life. Thelin writes:

The university statutes did not exert complete control over students' activities. Students fended for themselves in lodgings and were under scrutiny of the masters only in certain situations. The university was not a residential campus; colleges or hostels were halls set up for indigent students, but hardly shaped the whole of student living. There was no claim that the institution would provide "socialization" for the region's privileged youth; i.e. it was not "elite" education. The curriculum was an important influence on modern practice as evidenced by today's conventions of syllabi, lectures, examinations, and degree requirements arranged in a systematic, accountable manner (Thelin, 1982, p. 36)

In the FSU, students socialize within a city, rather than within a university. Here university communities are open.

Corruption is concealed in the fact that many universities attract prominent sportsmen to the publicly funded programs disregarding their academic promise. This is known as an ethical issue in intercollegiate athletics. Universities in the US provide a lot of social events for their undergraduate and sometimes graduate students. Sports and athletic programs are a subject for on-going debates and are often linked to unfair admissions, tutoring, grade inflation, cheating, plagiarism, and other forms of misconduct. This form of corruption is certainly not a legacy of the medieval university.

Many of the student activities and their lifestyle patterns are formed within certain surrounding social environments. Different university settings, which vary from inner-city universities with no campuses to remote university campuses-towns, influence student behavior and academic process. 
Medieval-looking university campuses in the US are an invention, an artifact. As Thelin points out: "The medieval university had no campus; chronicles and diaries indicate that hostels and colleges were undistinguished lodgings scattered throughout the town. Classrooms would be hard to locate, as each master made his own arrangements for renting lecture halls, which tended to be inexpensive, nondescript structures subject to change from term to term." (Thelin, 1982, p. 37) In the FSU, many universities have their buildings spread out across the city. Central campus or building that hosts university administration is not necessarily the largest one. There are few exceptions to it, including such flagships as Moscow State University in Russia and Kharkov National University in Ukraine, but even they have several buildings distant from the major one. Groups of student dormitories that belong to different universities are spread out around the city, not necessarily close to the university buildings or academic facilities.

Misappropriation and misuse of university facilities and premises is a common disease for many higher education institutions in the FSU. An abuse of public property can take many forms. A student dormitory supervisor is normally highly corrupt and his/her subordinates are his/her good followers. In the dormitories where international students reside and constitute significant percentage of all dwellers, the rules are unobserved and broken, and corruption is flourishing.

The more auxiliary amenities and businesses university owns and manages the more corruption one may account for. For instance, Medical centers and hospitals are immanent part of many universities in the US, as they were in the medieval universities. While in the Middle Ages there were no such thing as medical malpractice or misconduct but rather a medical practice as a constant discovery, now any intended misconduct in a university-affiliated medical unit may be regarded as a corrupt activity. Good example would be a Federal law, according to which any 
medical unit or a doctor who receives Federal funds in any form is required to provide patients who do not possess necessary ability of spoken English with interpreting services at the expense of a hospital or treating physician. All university hospitals and medical centers are subject to this law. At the same time it is difficult to find a place where this law will be followed closely. Often medical personnel and administration are simply unaware of these requirements. In other cases this information is concealed so to reduce the potential cost of rendering medical services to the patients. This practice is illegal and adds to corruptness of universities.

\section{Financial affairs}

Financial affairs were always fundamental for the university functioning. Kibre gives the description of the financing function of the nations in Bologna:

The revenues of the nation were derived from the several sources. Chief among these were the sums varying in amount from two to fifty solidi, according to the student's income, paid upon the entrance to the nation. Occasionally a student added to his original contribution at a later time. There were also special assessments which the nation's members paid and frequent voluntary gifts as well as bequests from former students or friends which helped to balance the budget. Contributions on several occasions came from individuals seeking to assuage their consciences or to make atonement for past deeds of omission and commission, and there was an occasional gift from a grateful recipient of the license or doctorate. A further, not to be neglected, source of income was that from the fines or penances which the nation collected. In addition a small annual income was derived from a vineyard deeded to the nation by a former member. For some time the vineyard was occupied by the nation's beadle who paid a rent of four solidi each 
year for it. That the nation's finances were not always in a flourishing state is indicated by the reference to money-lenders to whom the belongings of the nation had been pledged as security for a loan. In 1289 the proctors paid out three pounds and five solidi for a loan of twenty-seven pounds (Kibre, 1948, p. 33).

University funds were consolidated based on revenues from the entrance fees, tuition, one-time, lump sum or occasional payments, gifts, donations, fines, and loans from money-lenders at the twelve per cent rate.

Universities in the US accumulate endowment funds, while in the Soviet system funding of higher education was of pay-as-you-go type, based on consolidated budget. The annual budget was distributed among universities by the Ministry of Education or the other Ministry that represented a certain branch or industry of the planned Soviet economy and all funds were spent within a year. The primary task of university administrators was to struggle for funding from the central government. Now situation changes, and while public universities continue to receive funding from state ministries, they are also allowed to accumulate funds on their institutional accounts. Private universities cannot compete for state funding and so they only exist thanks to the revenue from tuition, fees, and research activities. This makes financial survival a priority. One of the consequences of this is a declining quality of education and degrees conferred. Universities compete for students' tuition rather than for academically strong students. Lowest passing grades are often assigned to underperforming students in order to preserve student population at the expense of prestige and quality of the degrees, conferred by the institution.

Endowments and borrowing in medieval universities are described by Rashdall:

Endowments, (such as we find elsewhere) left to be expended in loans were no doubt a wise and useful form of charity at a time when the Jews were the only money-lenders, 
and when it was necessary to prevent the Jews of Oxford from charging over forty-three per cent as annual interest on loans to scholars. This institution was now introduced at Oxford for the especial benefit of scholars. The money accruing to the university was placed in a chest at St. Frideswide's in which the borrower was required to deposit some pledge - a book or a cup, or a piece of closing - exceeding the value of the loan. Pledges not redeemed within a year were sold by public auction. In time private bequests were added to the Frideswide chest, and the foundation of similar chests became a favourite form of benefaction, the recipients being required to make some recompense for the founder's liberality by saying a stipulated number of prayers for the repose of his soul. Some twenty of these chests were established at Oxford in the course of the Middle Ages. Some of the ordinances allow the university or a college to borrow. The administration of these chests was generally governed by conditions laid down in their deeds of foundation. A sum of money having been given for the formation of a chest, the university appointed keepers to be responsible for its administration. The keepers of a chest usually held office for a year and a month. A fixed scale of loans was laid down, varying in amount according to the academic standing of the borrower, and it was the duty of the keepers to accept adequate pledges (cauciones) as security for the money lent. Books were a very usual form of caucio. Before a book was accepted by the keepers of a chest, it was required that it should be valued by one of the stationers of the university, so as to ensure as far as possible that the loan was sufficiently covered by the caocio that was to be deposited in the chest in consideration of the loan (Rashdall, 1936 (c), p. 36).

It appears that financial survival was always a primary task in the medieval university. Financial mechanisms as well as administrators and appointed financial officers were already in 
place in the Middle Ages. Borrowing money in exchange for security deposit was a normal practice. In this regard, one can make a prediction that educational loans, both private and state, will soon become one of the major forms of financing education in the FSU. This new trend will most likely broaden the base for wrongdoing, misappropriation and misallocation of funds, embezzlement, and corruption.

The practice when professors lend money to their students in order to attract them to classes is now unheard of, but the concept itself is excellent. One can think of private colleges lending money to their students in form of educational loans. This investment creates a strong incentive for the college to update its programs, work on students' placements, and watch quality of the degrees. If the college wants to receive the loan back, it should make sure that the graduate will be able to repay the debt. In this case, universities will do marketing research for students, and students themselves will have institutional support on the job market. Now students identify what professions may be in demand in the near future and universities are driven by the students' demand. If universities will provide students with educational loans, then universities will be very interested in investigating what type of professionals will be in demand on the labor market. They will adjust their programs accordingly to secure good placements for their graduates. The well-placed graduates will then repay the debt.

Rait presents an idea of how doctors made their living from operating gambling houses and landing money to students:

Gaming and borrowing from unauthorized money-lenders were strictly forbidden; to enter a gaming-house, or to keep one, or to watch a game of dice was strictly forbidden. The University of Arts and Medicine granted a dispensation for three days at Christmas, 
and a Rector might use his own discretion in the matter. The penalties were fines, and for contumacy or grave offences, suspension or expulsion.

There are indicators that the conduct of the doctors in these respects was not above suspicion; they were expressly prohibited from keeping gaming-houses; and the appointment of four merchants of the town, who alone were empowered to lend money to students, was a protection not only against ordinary usurers, but also against doctors who lent money to students in order to attract them to their lectures. That the ignominious position of the Bologna doctors had an evil effect upon their morals, is evident not only from this, but also from the existence of bribery, in connection with examinations for the doctorate, although the corruption of this kind was not confined to the studentuniversities (Rait, 1931, pp. 33-34).

Professors in medieval universities were very inventive in generating their incomes and quite distant from what is now regarded as a dominance of professional paradigm over the material incentives. There was a documented case when two professors in a medieval town, one a good teacher and another one isn't, split the courses they would teach to the students. By this manner the good professor taught the course he was best at, and not so talented professor took the remaining course. Both of them collected tuition directly from the students. Afterwards, not so talented professor paid part of his revenue to the good professor. In the field of corruption such a payment is called a "kickback." In healthcare law this situation is determined as a felony. At the same time, in economics it is a classical scheme of the comparative advantage.

There is a rhetorical question whether the root of corruption is in corruptness of an individual, i.e. corrupt personality with its culture and believes, or an individual becomes corrupt due to certain circumstances, and what comes first: a corrupt person, who then uses favorable 
circumstances, or certain circumstances, that urge individuals to be involved in corrupt activities. The answer would be "both," if considered in a socio-economic context, where financial survival of the university and its professors is always a dominant factor.

In early Middle Ages, universities were not well-organized and so there were no such thing as salaries for professors. Later, paid positions were established in some universities. These positions were funded from the budget of a local noble, city council, or a king. This system reminds endowed chairs and professorships in the US. Compayre describes situation with professors' salaries in medieval universities:

In the earliest times there was no question of regular appointments and salaries paid from the public treasury, except in the case of certain universities generously supported and indorsed by the heads of the State. By degrees, however, there appeared, at least for a certain number of chairs, the custom of fixed salaries, drawn either from the general revenues of the university, the municipal treasury, or the liberality of princes. "In the fourteenth century at Bologna," says Savigny, "the majority of the professors were already salaried by the city, and the custom of paying all of them was soon established. Thenceforward, also, the professoriate was considered as a public function, which it had not been before." Thus, at Montpellier, about the year 1500, the emoluments of the professors of medicine amounted to one hundred livres, those of the professors of law to fifty livres, while the professors of the Faculty of Arts had only thirty livres. At Bologna, where people were richer, the salaries of jurists varied from fifty to nearly five hundred livres.

These were exceptions. In the majority of the universities, especially in the Faculties of Arts, professors continued to receive the fees for their instruction directly from the pupils. 
"The University of Paris," said one of its rectors at the beginning of the eighteen century, "finds itself reduced to the sad necessity of demanding a mean and miserable sum from its scholars in order to maintain its masters." The result of this dependence on pupils was, as one can imagine, a tendency on the part of professors to display indulgence and to lower the requirements for passing the examinations, so as neither to discourage the students nor to expose themselves to the loss of patronage. In 1412, a rector of Montpellier called the doctors of the Faculty of Law to order for their deplorable laxity in conferring degrees. Poorer universities acquired a sorry reputation for excessive laxity; the graduates of the University of Orange, for instance, were nicknamed "Orange-flower doctors! Docteurs a la fleur d'orange!" (Compayre, 1893, pp. 283-284)

Practice of establishing salaries for professors reminds the soviet system. The Soviet system was more advanced in this sense, because not only it provided salaries from the state budget, but salaries of professors were scaled on the basis of academic merit and scholarly rank, not the specialty or a major. Higher education was nationalized and professorial positions were public. Field or discipline did not play any role in the amount of money earned by professors. Now there is a mixed system in public universities, when part of the salary comes from the state budget and the other part comes from for-tuition programs. There are numerous for-tuition programs in economics, management, foreign languages, jurisprudence, medicine, computer sciences and so salaries of faculty members vary depending on the discipline.

In private universities, salaries are independent from the discipline, even though all programs are financed by students through tuition and fees. In the US student payments to professors are made through the chain of bureaucratic links, but the principle is the same as in the medieval universities. Salary scale varies significantly by discipline in both public and 
private universities. As it was in the medieval universities, professors attract students to their classes. Often salaries of professors are placed in direct dependence from the students' evaluations. This leads to the grade inflation that undermines quality of education and corrupts higher education. For instance, at Harvard seventy percent of undergraduate students receive A and A- only. Harvard professors recognize that the last twenty years were marked by grade inflation.

Not long ago, Harvard community was discussing an issue of whether the university should invest into the Israeli economy. It was considered by some as an unethical investment due to Israel's aggressive policy toward Palestinians. Another example would be the initiation of a lawsuit in the court of New York against the Russian oil company Surgutneftegaz [Oil and Gas of Surgut]. Harvard was unsatisfied with the rate of return on its investment into the stocks of this Russian company, traded on NYSE (Newsru, 2004). An impressive financial outreach of this institution of higher learning and research is obvious. This process may be formulated as "the institutional takes over the functional," i.e. institutional autonomy and financial soundness becomes more important, than the core function of selecting and educating students.

Medieval universities were not homogenous. They utilized different organizational forms and their financial affairs were regulated differently. If in the Middle Ages professors operated gambling houses, now many professors are involved in entrepreneurial activities. Private consulting outside the university is a widespread form of receiving money directly from the students. In many cases, price for private consulting done by the professor is in fact a legalized bribe rather than a payment for instruction. This phenomenon has become known as private tutoring and is now widespread around the former Soviet republics. 
Financial affairs are now institutionalized and well-administered, but the principles are the same in all private universities: the institutions collect tuition from students and then redistribute it through the university budget to cover the needs of the institution. One can assume that there are no faculty members who keep gambling houses, but gaming itself is now an institutionalized, regulated, and well-developed corporate industry. More important, as it was in the Middle Ages, many professors are now gaming in selling admissions, grades, and degrees. Since the risk of penalty for these activities is often rather virtual than real, corruption is becoming more of a business, than of a gambling.

\section{Misconduct and informal relations}

Developing the relationships may be the key to academic success for the student. Key says that: “... the act of bribery is a matter requiring considerable skill. In the process there is often considerable preliminary negotiation in order to achieve an intimate relationship with the person to be bribed. He is given "good" and plausible reasons for doing what he is being bought to do. Sometimes advantage is taken of his financial needs, and he may be in a way coerced to accept. In other cases, of course, bribery is a more or less cold-blooded commercial transaction." (Key, 1934, p. 387) Many corrupt professors justify their actions by their unfairly poor economic conditions and overall crisis of morality in the society. Moreover, they are often persuaded by the donors with the saying that the instructors are not well paid and that everyone has to feed one's family.

In the medieval universities, academic process was not free of what is now known as misconduct and informal relations. Haskins writes: "The great ordeal of the day was the master's quiz on Latin grammar, when every one was questioned in turn (auditio circuli). The pupils 
rehearse their declensions and conjugations and the idle begin to tremble as the hour draws near. There is some hope that the master may not come. "He has guests." "But they will leave in time." "He may go to the baths." "But it is not yet a whole week since he was there last." "There he comes. Name the wolf, and he forthwith appears." Finally the shaky scholar falls back on his only hope, a place near one who promises to prompt him.” (Haskins, 1957, p. 74)

In early times of market reforms in the FSU, when every professor of economics or finance was actively involved in the development of newly emerging private firms through consulting and direct participation, many professors tried to skip some of their teaching time in lieu of their outside commercial activities. By now these practices are more or less under control of the departments and college administration, but in early 1990s it was not unordinary for the students to see how their professor is trying to walk away from the university on the other side of the street right before his class is scheduled to start.

Students who now pay tuition finally realized that this is their money paid to professors who do not show up for their classes, start the class late, or dismiss the class earlier. If in Soviet times students were struggling for high grades, now many have to demand from professors to obey the rules and work the class-time. It is also true for many universities in the US, where professors tend to start weekend classes later than the schedule says and dismiss the students well before the class should end according to the schedule. This invisible corruption is nothing more than the class-time, paid for with students' tuition and stolen from the students.

Students in the medieval universities faced similar problems. Thelin writes:

Students also expected masters to fulfill obligations. At the start of a course, the master outlined materials to be covered, the fee schedule, provisions for review, and classroom procedures. Some masters concluded a course with a preview: It is an ancient custom in 
this city that when a book is finished, mass should be sung to the Holy Ghost, and it is a good custom and hence should be observed. But since it is the practice that doctors on finishing a book should say something on their plans, I will tell you something but not much. Next year I expect to give ordinary lectures well and lawfully, as I always have, but no extraordinary lectures, for students are not good payers, wishing to learn but not to pay, as the saying is: "All desire to know but none to pay the price." I have nothing more to say to you beyond dismissing you with God's blessing and begging you to attend the mass (Thelin, 1982, p. 33).

Hyde argues for the nonprofit character of medieval universities:

A century after the Habita the case of a societas without corporalia was recognized as a special problem by Odofredo, who expressed the opinion that the doctors and scholars of his day were, strictly speaking, not socii but contubernales - mere bedfellows - on the grounds that they did not combine together for profit. He tells a revealing story about two teachers of grammar, one of whom was popular and the other unpopular, who agreed to specialize in different aspects of the subject and pool their earnings. Odofredo did not say that this agreement was illegal, but he clearly felt it to be inappropriate, presumably on the ground that knowledge and academic talent could not properly constitute corporalia (Hyde, 1972, p. 36).

Professors of the Middle Ages were financially dependent from their students. Compayre writes: "Characteristic of the professor of the Middle Ages is that he was too dependent on the students. How was a man to make his authority respected by pupils who perhaps had elected him, and who at all events paid him? There was at that time no superior administration, distinct from the university, and supplying it with professors of its own choice." (Compayre, 1893: 281) 
Similar situation is present in contemporary Russia and other parts of the former USSR, including Ukraine and Central Asia. In private universities, where salaries of professors as well as all the other expenses are paid from accumulated tuition and fees, students feel their significance and power. In public universities, where professors are paid from the state budget, situation is not much different. Salary for public workers, including higher education instructors and the administration, is often not paid in time. Arrays in salary in the FSU use to reach six to twelve months and more during the 90 -es. In the environment where everyone demonstrates rentseeking behavior, it seems irrational to stay outside of the "mainstream" of economic development, including corruption. Professors understand that their position presents them with significant opportunities for receiving benefits beside their miserable salaries. While in Russia corruption was not widespread during the Soviet times and was not well tolerated by the public, in Central Asia corruption simply became more open than it use to be, though still is regarded as would be illegal. Involvement in the illegal activities requires breaking personal ethics and certain norms of behavior and establishing new type relations with the same and new people and organizations. Russian higher education, however, chooses this way of adaptation to the new economic realities.

Opinions on corruption in higher education vary. For instance, the Rector of Moscow State University gave the following comment on the news about the arrest of two corrupt professors in one of the Russian regions: "Until the country will start to think whom, what, and how it teaches, to organize demonstrative prosecutions for bribers in universities is immoral and not clever. It is a blasphemy to require high moral principality from a professor, who lives on \$50." (Sadovnichiy, 2001) Sadovnichiy sees causes of corruption among college teachers not in them, but in the way government treats them. He also suggests that: “...education in universities 
should be free. Of course, commercial education also should have a right to exist, but it should exist separately from public education.” (Sadovnichiy, 2001)

In times of major socio-economic transformations, it is unclear what is and what is not allowable, and what are the basic rules. People who are involved in corrupt activities often do not know the rules, interpret the rules in their favor, as well as arrange and adjust the rules. The only ground here is a mainstream of socio-economic development, at the top of which there is a new, i.e. adjusted old social order with its new laws and regulations. These new rules are only observed and followed if they adequately reflect the reality. Unfortunately, the new rules most often reflect quasi-reality that is reality that exists in people's imaginations and ideals about fairness and better social order as well as political proclamations, and so breaking a law means moving toward equilibrium in socio-economic relations rather than violating this non-existent equilibrium.

\section{Graduation and academic degrees}

Graduation is always a special event. It has its meaning and formal and informal traditions. Some of the traditions are quite "innocent" while others clearly constitute act of corruption. Rashdall describes graduation traditions, ceremonies, and festivities held in medieval universities and writes:

A fuller knowledge of the customs and ritual of the Italian guilds would perhaps reveal a tolerably close analogy between these ceremonies of the conventus and those by which other guilds of merchants, professional men or craftsmen, received a new member into their brotherhood. In obedience to an inveterate instinct of human nature, members so admitted, while welcomed with effusive cordiality, were also expected to pay their 
footing. The earliest custom was no doubt to send presents of robes to the doctors, bedels, and other officials taking part in the ceremony; but by the date of our statutes these presents were commuted into money payments, though a fixed quantity of cloth of a certain specified colour might still be substituted for some of them; and in addition to the regular fees there were also some customary presents - a cap, gloves, and a present of sweetmeats to each of the doctors and to the archdeacon, while the prior of the college claimed a ring. So at Pisa, the candidate is required to send each doctor a box full of comfits, of $1 \mathrm{lb}$. weight. But the greatest expense of all was the banquet which the new doctor was expected to give to his colleagues and university friends. Even more magnificent entertainments, such as tilts or tournaments, were at times provided by wealthier students. At some of the Spanish universities the incepting doctors were required to provide a bull-fight for the amusement of the university. The immense scale on which these inception rejoicings were carried out may best be estimated from the fact that the Council of Vienne in 1311 passed a canon limiting the expense of such entertainments to '3000 solidi tournois'. It should be added that besides the legitimate expenses of graduation, bribery was by no means unknown in the Bologna examinations. The Jurist Francis Accursius took the precaution to get a Papal absolution for the 'munera' which he and his father had received from L. Faminando (Rashdall, 1936 (a), p. 227).

In the Soviet and post-soviet times this absolution comes from the state, which guarantees the degrees, while in the US big pomp is always present during commencement in order to give more weight and significance to the degrees. US universities are obviously champions in showoff. 
Examinations in the medieval universities were complex, but this complexity was often compensated by the laxity of procedures or examiners:

Complexity, as one sees, was not lacking in the form of the examinations of the Middle Ages. Never was beheld such a profusion of formalities, pompous ceremonials, solemn engagements and oaths, private and public argumentations, discourses and harangues. Never, moreover, did it cost more to obtain degrees, especially the higher degrees. To arrive at the doctorate, particularly, one needed to be actually rich, rich in money still more than in knowledge. At Salamanca, to intrigue for the honors of the doctorate, one of the formalities required from the candidate was to defray the expenses of a brilliant corrida de toros. Elsewhere, and almost everywhere, it was a question of paying for sumptuous banquets. At Bologna, the doctor-candidate had to furnish closing for a large number of persons. Savigny relates that, in 1299 , when the promotion was refused to Vianesius, whose fault was that of not being related to the doctors whose duty it was to receive him, he had already spent five hundred livres in buying scarlet cloth for pelisses. In 1311, Pope Clement V decreed that the candidate should swear not to expend more than five hundred livres for his promotion (Compayre, 1893, p. 161).

While corridas are gone, banquets are often impressive. In one case, the head of the tax administration of one of the districts, who just arrived to her doctorate, invited twenty-five members of the doctoral committee to a mansion built especially for the meeting of the presidents of Russia and Ukraine. The meeting did not occur, and the mansion was used by those who had an access to it.

Doctorate became a title, a verbal distinction, a feature of nobility. Ever growing administrative regulations imposed on the universities and doctoral committees in order to 
oppose corrupt practices often lead to the opposite results. Those who have means to meet all the bureaucratic requirements defend their thesis while many of those who are not well-positioned in terms of access to the resources give up on their doctoral work. These are medieval practices. Compayre comments that: "To arrive at the title of master a man expended his patrimony and exhausted the purse of his friends; he often remained in debt and needy for the rest of his life." (Compayre, 1893, p. 162) Some departments are famous for their banquets while others are not. Nevertheless, moderate banquets after the doctoral defense are rather a good tribute to a good tradition than an act of corruption. Banquet is in many cases is an informal continuation of formal procedure of the defense.

Doctoral defenses in the US are closed and not publicized. Normally there are only five or six people present, including the candidate. This system, if implemented in the FSU, would seriously undermine credibility of the defense and the degree. There would potentially be a lot of room for a concealed agreement and other corrupt practices. In the FSU, doctoral defenses reflect those held in medieval universities. All the defenses are open and public and all of the procedures are known in advance and publicized. Anyone can come and present critiques of the thesis. The candidates are required, among other ways of publicizing, to disseminate summary of their thesis among the leading universities and academic libraries of the twelve former Soviet republics (except the Baltic States). Worth noticing, that doctoral defense in both the FSU and the US is one of the few places where disputation occurs. In the FSU, such disputations are always well-attended and attract forty to fifty scholars.

A word should be said about the thesis editorials. In medieval universities, those who didn't achieve proficiency in Latin used help of their colleagues to accomplish the work. In the US, it is a normal practice to turn a doctoral or a master thesis to an editor. This service is not 
free, but as was noticed by a university administrator "this money is worth paying, because people in the Graduate School will not pay much attention to the format if the thesis is signed by the editor they know, but if it was not edited, than they will measure every millimeter." The right of discretion creates opportunities for corruption. In the FSU, editing is not illegal, but among the scholars it is often regarded as a form of corruption. Numerous documents submitted before and after the doctoral defense add to the complexity of the defense. Preparation of the package of documents by some outside consultants may cost a sum that equals to an average salary for six month. In some universities it may be well-organized and cost a little fee, which is rather a rational approach than corruptness of the procedure. In many instances, the entire environment surrounding the defense may be characterized as an organized anarchy, if not an organized chaos.

Evidently, students at undergraduate programs are not expected to serve any banquets, although in some institutions they may invite some professors to join them celebrating graduation or prepare a collective present to the examiner. In this sense, medieval universities were quite different. Compayre describes some expenses student has to bear to the bachelor degree:

The baccalaureate and the licentiate were evidently not so costly as the doctorate, that actus triumphalis of graduation. But for these degrees also there was considerable expense for display. It has been said that in France everything ends in song; in the universities of the Middle Ages everything began and ended with banquets. A banquet before and after the determinance; a banquet after the license; a banquet after each act of the mastership; banquets always and everywhere. And these banquets sometimes assembled the whole Faculty, all the masters in arts, all the licentiates. Ramus 
complained, in the sixteenth century, that of the nine hundred livres which medical studies cost, three hundred were devoted to banquets (Compayre, 1893, p. 162).

Worth noticing, that the medical education those days, as well as now, was the most expensive type of training. Three hundred livres for banquets in medical school were, in fact, satisfactory payment for the entire course of study in arts.

Clearly, in the FSU, a student can receive his/her degree as a result of paying bribes or as a result of his/her studies without any extra expenses. The variety of goods and services offered as a bribe or gratitude is as impressive now as it was in medieval universities. Below is an incomplete list of in-kind bribes given by food and manufacture in many higher education institutions of the FSU.

Food items normally used for bribes are: alcohol, candies, cakes, coffee, other. Alcohol includes cognac, vodka, vine, and champagne. These are goods-symbols of corrupt educational environment. There are stores-satellites emerging near the universities. Good example would be the new liquor store "Ararat" across the street from Donetsk State University, one of the leading public universities in Ukraine. The liquor store specializes on the original and expensive imported liquors and sends a clear message to those students who are looking for settling their academic problems. Quite possible, there is an expression among the students of the university that "this problem can be solved across the street."

Manufacture items are: perfumes, clothes, tape-recorders, TVs, refrigerators, computer diskettes, vacation packages, office supplies, books, rarely cigarettes, jewelry, cars, and pets.

Services rendered as bribes include: typing, printing, copying, dentistry, car services, accommodation in resort areas, home repair, job placement, acceptance in higher education 
institutions and grades in exchange for similar favors, settlement of disputes, arrangements, access to internet, and, as follows from the media reports, more and more often, sex.

Public tolerates gifts, i.e. bribes in kind and services much better than it does cash and especially foreign currency. This may be considered a legacy of medieval university. In Middle Ages, money-commodity relations were undeveloped and money was not used on the regular basis for market transactions. In times of high inflation and currency crises, bribes in kind and services are a good substitute for money.

It is understood, that the bribes are given in exchange for admissions, grades, and degrees, rather than as a sign of respect. In turn, the examiners are expected to demonstrate certain laxity in regard of students. It is true now and it was true six centuries ago. Compayre asserts:

The examiners showed extreme indulgence. They were sometimes obliged to reverse their decisions. It must not be forgotten that the degrees were one of the principal sources of revenue to the professors. Not a single case of a candidate who failed is found on the register of the Paris Medical Faculty from 1395 to 1500. The examinations were often mere formalities. Even this might be excused if attendance at the courses had been rigorously required. But dispensations were frequently granted; and to pay for it was sometimes all that was necessary to obtain the certificate of attendance during the scholastic term. Abuses were increased by the multiplication of universities; they became each other's rivals and sold diplomas at a discount. "Composed of a small number of masters and students," says Thurot, "the provincial universities were lax in their examinations and even sold their degrees. Students bought their bachelor's degree there and went at once to Paris to obtain their license. But even at Paris trickery and corruption 
insinuated themselves even into the solemn decisions pronounced when degrees were conferred. The examiners willingly displayed a certain partiality toward the nobles and the great.

To sum up, in all that concerns the conferring of degrees, the universities of the Middle Ages seem to have drawn up admirable regulations on paper, much better ones than they succeeded in enforcing. It is in the system of examinations that their laxity is perhaps most evident - it appears also in the lack of discipline of the students, in the lack of regularity on the part of the professors - in the vices inseparable from a democratic government, where the chiefs, usually elected, were not always sufficiently independent to resist solicitations and offers of money, and where some anarchy was mixed with a great deal of liberty (Compayre, 1893, pp. 163-164).

State examinations held before graduation in the FSU are often a mere formality. Also, students have a right to retake their final examination at least two times. Often students take their examination until they pass. Students who fail the examination several times should take the examination in front of a committee. Some students offer a bribe to the examiner after the first failure while others choose to pay a bribe instead of staying in front of the committee. These mechanisms of retaking examinations and paying bribes to obtain a pass are a direct legacy of the medieval university. Rashdall consider examinations in medieval universities and all the laxities they assumed:

The word 'Examination' had even at Paris a wider sense than it bears in modern times. It included any process of inquiry into the candidate's fitness, as well as a direct testing of his scholastic attainments. We have seen, however, that at Paris there was always an examination in the modern sense by the chancellor and the faculty or examiners selected 
therefrom. If in the superior faculties this examination was reduced to a mere formality, that was not the case in the faculty of arts, and in all cases there were real examinations at earlier stages of the candidate's career. At Oxford it is a curious fact that we have no express evidence of the existence of examination in the literary sense of the word. For the inception of license the statutes are silent about the existence of any examination whatever. When a candidate presented himself before the chancellor for the license in arts, he had to swear that he had read certain books, and nine regent masters (besides 'his own' master who presented him) were required to testify or 'depose' to their 'knowledge' of his sufficiency (de scientia), and five others to their 'belief' therein (de credulitate). In the faculty of theology all the masters were required to depose de scientia, a single adverse vote being fatal to the degree. Whether the masters had any other means of judging of the candidate's knowledge and capacity than had been afforded by his performances in the various disputations required for the degree, cannot be pronounced with certainty. In the superior faculties they undoubtedly had not. In the faculty of arts there seems an a priori improbability in supposing Oxford and Cambridge to have been in this particular totally unlike all other known universities. Yet it is practically certain that there can have been no regular board of examiners or temptators such as existed everywhere else, who formally examined the candidate in the subject-matter of his books (Rashdall, 1936 (c), pp. 141-142).

In the FSU, corruption during graduation consists of two extremes. On the one hand, there are relatively low expenditures that normally consist of traditional presents to the faculty and negotiations for higher grades on the state examinations and theses. The thesis itself can be bought for the price of about $\$ 100$ - $\$ 200$ from academic supervisor or the outside faculty, and 
for $\$ 50$ to $\$ 100$ from the student or any other non-faculty member or administrator. Price of the thesis depends on the major and rank of the school. On the other hand, the most expensive illegal service is sale of the diploma. Selling of the diploma is relatively risky business, since person who will obtain the job with the bought diploma can later, if falls under investigation for the other serious crime, can cause further investigation. Problem is that technically person has to be enrolled for five years in the college. It, however, may be falsified by indication of enrollment on correspondence courses.

Price of the diploma starts from $\$ 500$ and depends on the rank of the school and the major. One may speculate that the diploma from the top-ranking school may cost several times more than from private or local public college. Relatively cheap diploma from a private university is normally purchased to have a good or necessary educational ground for the occupation that person already holds, or is agreed to occupy immediately after "graduation" based on the presented diploma and/or other educational credentials. Diploma from a top university can be bought for the reason of prestige.

University statutes of medieval universities inscribed certain policies in regard of gifts and other contributions in order to prevent laxity in examinations and corruption: "To curb corruption in examinations, the statute said, "no one is to receive a license from the chancellor or anyone else through a gift of money, or furnishing a pledge or making an agreement." (Thelin, 1982, p. 32) While in the FSU admissions, grades, and degrees are often sold through the direct transaction, in the US universities admissions are often granted based on such characteristics as legacy factor, when parents are alumni of the university, gifts, donations, different contributions to the institution, department, or program, and personal contacts. 
In decentralized educational systems many non-accredited institutions are free to place their degrees on sale legally. Until there is demand for such services, there will be supply. Thelin (1982, p. 41) gives the following example of a diploma for sale: "One reporter documented a company's offer to supply a customer with a "beautiful, exacting copy" of a Stanford diploma for \$45. Extras, including designation of major, department, or cum laude, were available at added cost. The number of complaints about the bogus degrees was so large that the State of California pressed charges against the soliciting company; individual campuses created form letters and files for dealing with "Doubtful Princetonians," "Columbia Special Cases"” and other academic imposters." While in the FSU no one would ever expose his diploma or certificate publicly, in the US it is common to place a framed diploma in your office or a workplace. And since it is important, why wouldn't one frame and expose on his/her office wall a Stanford diploma recently acquired for $\$ 45$ ? Some clients may feel more respect to their agent, if his/her office is decorated with a genuine-looking Stanford diploma. It becomes rather a question of trade mark than honesty.

Honorary degrees are also in demand. Thelin presents the following fact: "One institution which was struggling to bolster its endowments ran advertisements in national literary magazines for a "genuine" honorary Ph.D., printed on the "same high-quality imitation sheepskin used by leading colleges and universities, for $\$ 150$." The idea was that the institution would trust candidates to set and fulfill their own advanced study requirements; these would be duly acknowledged by the institution once the candidate had submitted has donation/processing fee. One could argue that most established colleges and universities grant honorary degrees to persons far removed from educational, academic, or intellectual pursuits." (Thelin, 1982, p. 41) 


\section{Degrees and hiring for faculty positions}

Doctorates today are necessary to obtain or occupy a teaching position in a higher education institution. Thelin writes in this regard:

Today one hears the lament that the Ph.D. has been debased to a union card for college teaching. In fact, that is its historic connotation. Medieval universities contributed to the formal recognition of scholarship as a profession; scholars who held degrees or licenses were a guild. Such professional licensing was taken seriously, as it gave teaching and scholarship a transcendent dignity and status. To receive the master's license meant not only that one had completed study requirements, but also that one accepted lifelong rights and obligations as an academic guild member. University licenses worked in to ways: their positive effect was to bestow honor and the privilege to teach; their negative, proscriptive dimension was to prohibit those who did not hold the degree from teaching. Thus, students were protected from educational malpractice, comparable to the protection buyers enjoyed against faulty crafts and services by tradesmen who were required to display their insignia and license (Thelin, 1982, p. 39).

In the medieval universities, doctorates were also used as a criterion or a guarantee of a quality instruction. But the dilemma was that while some of those who arrived to the doctorate could not provide a quality teaching, others, who had a good instruction, did not hold doctoral degrees.

Church officials intended to monopolize the function of issuing the teaching license. Compayre describes an action by the pope Alexander III intended to prevent bishops from monopolizing the right of conferring the license to teach: "At any rate, he formally forbade that any sum of money should be required from the candidates as the price of the right to teach, 
which was granted them, and he required that "any capable and instructed man" (idoneus et litteratus) should be authorized to keep school.” (Compayre, 1893, p. 142)

Teaching capacity of professors becomes an issue in medieval universities:

Originally, the license was conferred without an examination on whoever was held to possess the necessary aptitude. By degrees greater severity was introduced, principally in what concerned theology, the popes being specially interested in the teaching of it. In his bull of 1231, Gregory IX recommended the Chancellor of Paris to make a serious investigation of the capacity and the morals of aspirants for professorships: "Future chancellors," said he, "shall swear not to receive as professors of theology and canon law any but worthy men, able to do honor to their precepts, and they shall reject all who are unworthy, without respect either to persons or to nations (Compayre, 1893, p. 143).

In the FSU, doctorates constitute around fifty percent of the faculty. In some countries, including Ukraine, the general requirement for the higher education institution is to have at least sixty percent of the full-time faculty with doctoral degrees. This is a necessary condition to be met in order to receive the state accreditation. Only most prestigious schools can afford to have up to eighty percent of faculty members with doctorates. One of the reasons why conferring doctoral degrees becomes a corrupt business is that doctors are often welcomed to take a teaching position. Teaching position then presents an opportunity to collect bribes from students to compensate earlier expenses for obtaining the degree.

Control over the quality of instruction becomes a necessity and many first-year contracts with faculty members are now one-year contracts. Same system existed at the University of Paris. There were three month given to the incoming instructor as a testing period during which the Chancellor supposed to: "make inquires of the professors of theology and other serious and 
instructed persons, in order to become acquainted with the life and manners, the knowledge, capacity, love of study, perfectibility, and other qualities needful in those who aspire to teach; and, these inquiries finished, he shall grant or refuse the license according to his conscience." (Compayre, 1893, p. 144)

In modern universities, employment is often a subject of misconduct and corruption, when hiring of faculty is made on the basis, other than academic merit or scholarly potential. Biased hiring decisions are often made by the chair of the department to benefit his/her relatives applying for job or in exchange for a bribe. Fortunately, this mechanism often does not work. And the fundamental reason for this is that teaching in a university requires special skills. Chairs of academic departments are under pressure from two opposite sides: on the one hand, they are tempted to make a placement decision based on a bribe or nepotism, but on the other hand, they understand that university instruction requires an advanced knowledge and a talent to teach. In many instances, the latter reason appears to be stronger and wins. Also, since salaries of the instructors are low, it keeps many well-connected people away from teaching position in colleges. At the same time, it gives the opportunity for promising scholars to take teaching positions.

Finally, distribution of teaching time and tutoring are also issues linked to corruption in faculty hiring. Private tutoring by a faculty member should be considered a form of misconduct if it is a precondition for entering a university or receiving a positive grade. In such cases tutoring is highly overpriced. Also, many faculty members demonstrate low quality of teaching in class because they are heavily involved in tutoring outside the classroom. They simply redistribute their energy and time. This practice was most common for the teachers of foreign 
languages, but is now typical for almost everyone who is involved in any form of tutoring. Beside such cases, tutoring should be permitted as any other form of private consulting.

\section{Honorary doctorates}

Honorary degrees, normally doctorates and sometimes professorates, are awarded in recognition of contribution of a recipient into political, social, or economic life. Distinguished alumni also become recipients of the honorary degrees. Often these degrees are awarded by the universities in pursue of certain favors from the recipients. One should not exclude cases of direct monetary contributions and donations, or granting privileges to the universities as well. President of Azerbaijan, Ilham Aliyev, who graduated from Moscow State Institute of International Relations and was a faculty in this university afterward, was awarded an honorary doctorate during his recent visit to Moscow, as a tribute to strengthening relations between the two countries:

Meeting at Moscow State Institute of International Relations

President of the Republic of Azerbaijan Ilham Aliyev met with teaching staff of the Moscow State Institute of International Relations, where studied and worked as a teacher. Rector Anatoliy Torkunov pointed out in his opening remarks that President of Azerbaijan was the fist alumnus of this prestigious educational establishment to become a Head of State. He also told in detail about political activity of President Ilham Aliyev. President of the Republic of Azerbaijan Ilham Aliyev delivered a big speech at the meeting. Dwelling on the perspectives of Russia-Azerbaijan relations, as well as political, economic and legal reforms being carried out in the country, the Head of State stressed that this political course would be further continued. At the end of the meeting, President 
of Azerbaijan Ilham Aliyev was awarded diploma and the mantle of Honorary Doctor of the Moscow State Institute of International Relations. The Head of our State was also awarded diploma of Scientists Association of the Institute and the record-book of his student years. President Ilham Aliyev presented the work of Azerbaijani painter to the Institute and had conversations with its teachers. (AzerTAg, 2004)

President of Turkmenistan, Saparmurat Niyazov Turkmenbashi, received the Honorary Doctorate of Malta University from the President of Malta University, Alfred Joseph Baldachino (Niyazov, 2003).

There are fourteen Honorary Professorates conferred to those who hold professorships or research positions in higher education institutions and nineteen Honorary Doctors, including politicians and bankers, at the National University "Kiev-Mohila Academy," a leading higher education institution in Ukraine, first established in 1615 and then re-opened in 1992. Honorary Doctorates were awarded, among others, to the ex-president of Ukraine, Leonid Kravchuk, exprime-minister of Ukraine Victor Pinzenik, and former Chairman of the National Bank of Ukraine and presidential candidate Victor Yushchenko. Conferring an Honorary Doctorate to the President of Russian Federation, Vladimir Putin, by the University of Hamburg turned into epopee with hot debates among the university professors and attention of mass media (Newsru, June, 2004; July, 2004).

Conferring honorary doctorates and professorates is not necessarily something inappropriate. University of Oslo awards these degrees on the basis of academic merit, rather than based on economic and political motives:

Ever since 1902 it has been the practice of the University of Oslo to award honorary doctorates. In recent times this has ocurred every third year. Our awarding of the title 
doctores promovendi honoris causa is the expression of respect for eminent research and scholarly contribution. Moreover, the award of an honorary doctorate is an acknowledgement and appreciation of these researchers' valuable cooperation with the University of Oslo. The honorary doctors have stimulated, and improved professional standards amongst our own research community. By the means of awarding honorary doctorates, the University of Oslo offers sincerely felt thanks to these eminent researchers." (Honorary Doctorates, Oslo, 2000) The list of the doctorates is consistent with the above statement. All of the awarded hold their scientific degrees and academic positions and have contributed significantly to the university research and teaching.

Thelin (1982, p. 42) presents an advertisement by an individual seeking a doctoral degree:

Honorary degree wanted

Desire Ph.D. or honorary doctorate in business or business administration. Will gladly take necessary examinations and/or make suitable pecuniary or civic contribution to college of higher learning which is able and willing to bestow the degree on me. I am age 60, financially responsible and successful, Already have qualifications as follows: B.A. Cornell University, graduate work done at Columbia University (advertising), former president and general manager of highly successful radio-TV operation, and now president of a successful and lucrative real estate operation, 25 years resident of same city and am financial advisor to many of its local businessmen, am listed in "Who's Who in the West", 3-1/2 years member Board of Regents State Junior College, references of any nature can be supplied, good Dun and Bradstreet rating available. The worst I have ever done in breaking a law is to get one speeding ticket for going 70 miles per hour last year, 
no other violations whatever or ever! I should like to meet any requirement and receive sheepskin by March 25, 1978 and will not be easily available after that date. Have made many civic contributions such as founder, officer and director of local national bank, local Red Cross, city library building fund, founder and past president Rotary Club, etc. Write immediately to Box A2-105, The Chronicle of Higher Education or phone me at 801-259-5991.

Doctorates are often needed to put suffice of a Dr. before one's name. It gives feeling of self-respect and personal accomplishment. Verbal distinctions come, change, and disappear in time. Noble titles in France, inherited in generations and then simply sold by the Crown to the merchants, are now near extinction. Nobility in France was abolished while Britain still award titles of Sir to some distinguished contributors. The clear division between doctorates and honorary doctorates is a solution to the problem of academic credentials versus public merits.

Naturally, universities may request from the government to establish the state control over doctoral degrees and other academic degrees as well. Accreditation is still being an important institute in higher education. Doctorates are needed to pursue scholarship in academia and research. Knowledge is the best criterion of the genuine doctorate and professorship along with research achievements is a best usage of doctorates.

\section{Nationalism, internationals, and discrimination}

Universities are international by their nature. Universities were located in towns within the limits of kingdoms or feuds, but students were from all over Europe. Universities emerged in 1100s while the nation-states were shaped in XIX century with the development of capitalism. Meaning of a foreign national in our understanding did not exist at that time. There were no visas 
necessary to cross national borders and there were no passports and no citizenship. Student visas and all the abuses and corrupt activities linked to them are a disease of our days and cannot be blamed on the Middle Ages. Nonetheless, there are links that may be established. In the Middle Ages, students were granted special status by the Church and enjoyed special treatment, often outside of the control of local courts and townsmen.

Today, student visas give some privileges to their holders, including right to stay in the country of the host university. This legal status is often abused. There were attempts undertaken to organize accredited colleges as well as internship exchange programs in the US in order to be able to provide a legal cover for citizens of other countries to enter the US. It may seem surprising, but in the Russian Federation and Ukraine this problem is even sharper than in the uses. While in the US most of international students indeed study in academic programs, in Russia substantial part of foreign students comes to do their business under the cover of student visa status. A charismatic example of this would be Chinese students who trade with cheap manufacturing on the market from the very first week of arrival to the country and visit their host university only to arrange for their examination sessions. Such arrangements routinely anticipate bribes, often given in the very same manufacture that these "students" sell on the market. Unsold items are also of help.

Medieval universities conducted instruction in Latin and by this way created a neutral language atmosphere. This degree of universalization is unheard of in our days. Nevertheless, students belonged to the different ethos, spoke different native languages, belonged to different cultures, and came from different places. Finally, students were different from the locals. Verger writes: "The university was indifferent to the nationalist view and to patriotism because it officially adhered to Christian universalism. Yet at the very same time some foreign students 
were involved in litigations with the university before the Parliament. The occasion of these actions at law is immaterial; we shall only notice the xenophobia which often aggravated the resentment of the university against those students: a certain Paul Nicolas, a Hungarian and as bachelor in divinity, had to conduct a lawsuit from 1426 to 1431, when he was in danger of being expelled from his college and his nation." (Verger, 1972, p. 76) This case took place in the University of Paris. Xenophobia in respect to foreign students is not something extraordinary in universities of the FSU and the US. This may be one of the reasons why foreign students communicate between themselves and students from the host country are often not open for communications with the foreigners. This is true for the US and the FSU.

Haskins describes biases in characteristics of students from different places:

They wrangled and disputed not merely about the various sects or about some discussions; but the differences between the countries also caused dissensions, hatreds, and virulent animosities among them, and they impudently uttered all kinds of affronts and insults against one another. They affirmed that the English were drunkards and had tails; the sons of France proud, effeminate, and carefully adorned like women. They said that the Germans were furious and obscene at their feasts; the Normans, vain and boastful; the Poitevins, traitors and always adventurers. The Burgundians they considered vulgar and stupid. The Bretons were reputed to be fickle and changeable, and were often reproached for the death of Arthur. The Lombards were called avaricious, vicious, and cowardly; the Romans, seditious, turbulent, and slanderous; the Sicilians, tyrannical and cruel; the inhabitants of Brabant, men of blood, incendiaries, brigands, and ravishers; the Flemish, fickle, prodigal, gluttonous, yielding as butter, and slothful. After such insults, from words they often came to blows (Haskins, 1957, pp. 17-18). 
Heuristics and biases in ascribing certain characteristics, often not favourable, to the students from different places are true now as it was in the Middle Ages. Foreign or international students are welcomed by universities for their money and not for their knowledge. Highly qualified, yet heap labor of foreign graduate assistants is also of high value.

In the Soviet Union, inviting foreign students to study in universities was a form of outreach of the Soviet Empire, while in the US it is a twelve-billion-dollar-a-year business. In the FSU, foreign students constitute a stable basis for corruption. They are often considered as the primary donors who pay bribes not only to professors, but also to university administrators and other bureaucrats, who have the authority over their status and length of stay in the country. In the US, foreign students is a source of revenue and cheap on-campus work force. Foreign students are often discriminated and treated as second-best people.

In the FSU, even long after the collapse of the soviet system, nationals of the FSU were addressed as soviets, and students from overseas as foreigners. Following are certain, often anfair and offensive, ascribed characteristics of the foreign nationals in the FSU. Vietnamese are involved in illegal currency exchange; Arabs are alcohol abusers who attend expensive restaurants and use services of prostitutes; Africans are speculators; Chinese are trading on big markets with closes; Nigerians are drug dealers. These characteristics are based on extracurricular or professional activities that are attractive for the foreign students in the FSU. Over the last decade, conglomerates of Chinese students have turned into the most notorious business structures that have little to do with academic activities.

\section{Inequalities in universities}


Student population in medieval universities was extremely diverse not only in terms of nationalities, languages, and cultures, but incomes and wealth as well. Rashdall offers the following comprehensive description of wealth disparities among the students who belonged to different socio-economic strata:

The university students of that age were drawn from every class of society, excluding probably as a rule the very lowest though not excluding the very poorest. The scale of living varied as widely as the social position of the scholars. There was a scion of the princely or noble house who lived in the style to which he was accustomed at home, in a hostel of his own with a numerous 'familia', including poorer but well-born youths who dressed like him and acted as his 'socii' or humble companions, a chaplain, and (if young) a private tutor, besides the ordinary servants. At the other end of the social ladder there was the poor scholar, reduced to beg for his living or to become the servitor of a college or of a master or well-to-do student. 'Servitores magistrirum' were exempted from fees. At Vienna and elsewhere there were halls (styled Codrii or Domus Pauperum) whose inmates were regularly turned out to beg, the proceeds being placed in a common chest. In the Oxford halls there was a class of students known as 'battelers' who were required to wait on the others before sitting down to table. Originally, the 'batler' was a poor scholar who acted as the personal servant of the fellow who appointed him. Still poorer scholars were granted licences to beg by the chancellor. Many a man who would be ashamed to dig was not ashamed to beg; and the begging scholar was invested with something like the sacredness of the begging friar. To support a scholar at the university or to help him on a smaller scale by giving him something at the door, in return for as prayer or two, was a recognized work of charity in the medieval world. Menial service, 
again, implied less social inferiority in days when gentle youths were habitually brought up as pages to bishops or abbots. For these poor scholars the 'ladder' of a university career was let down by the partial or entire remission of university dues and lecture-fees; though in some cases the scholar who graduated in forma pauperis was made to swear that he would pay the fees if he ever came 'to fatter fortune'. But after all, as we see from the university records, it was only a very small proportion of the students in a university, and a still smaller proportion of university graduates, who belonged to the pauper or servitor class. The vast majority of scholars were of a social position intermediate between the highest and very lowest - sons of knights and yeomen, merchants, tradesmen or thrifty artisans, nephews of successful ecclesiastics, or promising lads who had attracted the notice of a neighbouring abbot or archdeacon. So habitual was this kind of patronage that a large proportion of university students must have been supported by persons other than their parents, whether related to them or not. The colleges represent simply an extension of this widespread system (Rashdall, 1936 (c), pp. 407-408).

If for medieval universities it was true that "many a man who would be ashamed to dig was not ashamed to beg," for universities in the FSU the opposite is true. While during Soviet times every summer many students were going to Siberia and other parts of the country to work as construction workers, now some students dig graves on city cemeteries. Though digging graves is also a privilege, because this business is monopolized and extremely corrupt. Digging graves is of cause a rare, exotic case, but many students trade with closes on the big open markets. It is now considered as something normal. Some students play dice or play cards for money. In US universities, many students work on-campus. 
For medieval universities poor student was a norm, but majority of the students were not in deep need. According to Rashdall, "Many university students no doubt lived in the direst poverty. There is a famous story of three students who were so poor that they had but one 'cappa' between them in which they took turns to go to lecture. Numbers must have lived on bread and porridge with a little wine and meat on Sundays and holidays.... But it would be a mistake to infer that the majority of students lived in this way." (Rashdall, 1936 (c), p. 409)

Poor students in the FSU become very inventive. Some of them make money by selling their notes during the examination session, some write term papers and thesis for other students, making from $\$ 10$ to $\$ 100$ per paper. A major distinction line may be drawn between students who live at home and those who live in the dormitories. Many of those who live in the dormitories are focused on physical survival. Students are assigned to the dormitories based on their academic department, and so dormitories where the biology majors live are extremely poor while economics students' dormitories are relatively well-to-do.

Haskins's description of living conditions of medieval students reminds those of contemporary students:

All types are represented. There is the poor student, with no friend but St. Nicholas, seeking such charity as he can find or earning a pittance by carrying holy water or copying for others, in a fair but none too accurate hand, sometimes too poor to buy books or afford the expense of a course in theology, yet usually surpassing his more prosperous fellows who have an abundance of books at which they never look. There is the well-todo student, who besides his books and desk will be sure to have a candle in his room and a comfortable bed with a soft mattress and luxurious coverings, and will be tempted to indulge the mediaeval fondness for fine raiment beyond the gown and hood and simple 
wardrobe prescribed by the statutes. Then there are the idle and aimless, drifting about from master to master and from school to school, and never hearing full courses or regular lectures. Some, who care only for the name of scholar and the income which they receive while attending the university, go to class but once or twice a week, choosing by preference the lectures on canon law, which leave them plenty of time for sleep in the class-rooms, spending the rest of their time drinking in taverns or building castles in Spain (castella in Hispania); and when it is time to leave Paris, in order to make some show of learning such students get together huge volumes of calfskin, with wide margins and fine red bindings, and so with wise sack and empty mind they go back to their parents (Haskins, 1957, pp. 63-64).

This tradition reached our days. The difference, however, is that while in the Middle Ages a university degree or university education did not give any special economic advantages, nowadays degree is a key in occupying a position. Recent graduates, who now return home "with wise sack and empty mind," are placed on work by their parents. This practice of nepotism is now flourishing and not just something common but rather a rule.

Wealth disparities lead to mistreatment and discrimination. Even a uniform has been introduced in some of the medieval universities in order to mitigate visibility of disparities in student wealth. Compayre describes this as follows: "Thence came the efforts made, both in Italy and France, to oblige all students to wear the same costume. The statutes of the University of Florence decreed that every one, barons, dukes, bishops, and cardinals, as well as the humblest students, should wear a uniform vestment. "In the University of Paris, no distinction existed between rich and poor, between nobles and commoners. ... In 1311, Clement V put a check on the prodigalities of newly made doctors, whose admission was celebrated by illuminations and 
banquets, by pointing out that these inordinate expenses were discouraging and ruinous to poor students." (Compayre, 1893, p. 270)

These days cloth is a way of exposing wealth. This is especially true for the FSU. In US universities, students wear very simple cloth and are not distinct depend on their wealth. Major distinction between the students in the US may be in car they drive, not in sloth they wear. Complex of inferiority that poor students develop is a legacy of medieval university. In the US, relative income equality within universities is explained by inequalities in access to higher education. In the Soviet system, inequalities within universities were explained by equality in opportunity in access to higher education. These inequalities were insignificant since the family incomes did not vary significantly.

In the FSU, there are certain wealth disparities among the students, but with declining number of governmentally financed places these disparities decline. Now, wealthy students attend more prestigious schools and economically disadvantaged students attend less prestigious schools. Based on the fact that in the Middle Ages representatives of all socio-economic strata attended same universities and shared same classrooms, one can conclude that the present income segregation in higher education institutions is a phenomenon of last three centuries rather than a legacy of medieval universities.

Patterns of student behaviour differed depend on student socio-economic backgrounds. Compayre writes: "How far from the example left them by St. Dominic" (a pupil of the University of Palencia), "who devoted entire nights to study, are these scholars whom the slightest labor disheartens, who spend their time drinking in taverns, or building castles in the air (castella in Hispania), and who transform their class-rooms into dormitories!" (Compayre, 1893, p. 277) The same is true for students in the FSU. While many devote their time to study in the 
libraries, others party in the dormitories and cafés and by doing this undermine quality and prestige of academic degrees.

Inequality is a very contradictory issue. Whether inequality itself or its consequences should be regarded as a form of corruption is a question which is addressed differently in different environments. In the US, one can sometimes meet a $\mathrm{PhD}$ student who works in a fast food restaurant during night shifts to make his/her ends meet, while in the FSU it would be nonsense, not to say about the Soviet times.

In the US, a PhD in political science can make his/her living from fortune-telling or bartending, while in the FSU this would be a country-wide anecdote. Today, however, many doctorates in such disciplines as physics, mathematics, and chemistry, work as cab-drivers, small entrepreneurs, etc. These disciplines are not in demand, and so are professors who teach them. A major perception brought from Soviet times would be that any type of income-based segregation and mistreatment is corrupt. Hence, servitors of medieval universities would be regarded as victims of unfair socio-economic conditions, and this form of academic apprenticeship would represent corruption.

In Soviet universities and later in the FSU, there is no such category as teaching assistant or research assistant. Full-time post-graduate students who pursue their doctorates receive service-free stipend and if they teach part-time, they are paid additional salary for this as lecturers. In US universities, inequalities are considered as something normal and most of the graduate students serve as teaching or research assistants. While post-soviet students are busy digging graves, their American counterparts create websites for the cyber-begging, a new form of repaying educational loans. 


\section{Publishing, books, and textbooks}

In modern understanding, a library is an indivisible part of any university, but it was not always this way. In the medieval universities, books were objects of trade. There were no clear division between books and textbooks. All books were handwritten and then copied by hand. This work was primarily done by the monasteries and was one of their key social roles. Universities were far behind in book writing and copying. However, with growing university education, publishing and copying of books became a big issue and universities assumed the role of regulators in this area. Books were expensive and so wealth of a student as well as of a university could be determined by the number of books in his possession. Books were rented and sold.

Haskins writes:

Whether rented or owned, the supply was not inconsiderable; on the Bolognese monuments each student has a book before him. So long as each copy had to be made by hand, accuracy was a mater of much importance, and the university had its supervisors and correctors who inspected periodically all the books for sale in the town. Moreover, at Bologna a constant supply of new books was secured by the requirement that every professor should turn over a copy of his repetitions and disputations to the stationers for publication. The principal books of law and theology were the natural outgrowth of university lectures. With demand and supply so largely concentrated in the universities, it is not surprising that these should have become the chief centers of the book trade and, as we should say, of the publishing business. So long as students could rent the books they required, there was less need for libraries than we might at first suppose, and it was quite natural that for long the university as such should have no library. In course of time, 
however, books were given for the use of students, chiefly in the form of bequests to the colleges, where they could be borrowed or consulted on the spot. By 1338 the oldest extant catalogue of the Sorbonne, the chief Paris library, lists 1722 volumes, many of them still to be seen in the Biblioteque Nationale, while many an Oxford college still preserves codices which belonged to its library in the Middle Ages (Haskins, 1957, pp. 38-39).

In US universities, libraries have substantial funds, but attendance is low. It is explained by the fact that all undergraduate and graduate students buy their textbooks as well as course packs in a bookstore. Prices in university bookstores are normally ten to thirty percent higher than on the market. Many students turn books for resale. Textbooks are expensive and may cost as much as $\$ 200$. Mass production of textbooks abolishes the need in renting them. Seventh edition of the textbook may be not much different from the first edition, except for the price that may double in ten years.

The Soviet and then post-soviet system is quite different. Every student receives a set of textbooks from the library at the beginning of the semester and returns them to the library at the end of the semester. Soviet public and university libraries were always known for the richness of their funds and high rates of attendance. Many leading schools and departments as well as newly established private colleges in the FSU publish their scholarly works as monographs, textbooks, and course materials, and teach courses according to them. Professors are free in the selection of textbooks and teaching materials to cover the general curricula. Curriculum is defined by the faculty and may be slightly changed and updated from year to year. Many professors teach individually designed advanced courses, based on their scholarly interests and specializations. 
There is no significant corruption in promotion of the selected textbooks. Often academic departments publish textbooks at their own expense and then distribute to the students. Price is normally very low and affordable. It is very beneficial for the students and in fact is done with the time and energy sacrifice of the faculty. The department or the authors do not earn any profit on selling books. Revenue is generated to cover the costs of printing. Printing agencies do receive profit for production of books. They, however, do not take the risk of low sales and financial losses. Accusations that publishing and assigning textbooks to the universities is corrupt are a big myth. Earlier it was monopolized by the Ministry of Education, though it did not have any significant impact on the quality of the textbooks, and by now publishing is a sector open sector for entrepreneurial activities.

\section{Ethics and code of conduct}

Ethics and code of conduct for students and faculty were always on forefront of university life. Troublesome behaviour of students was as typical as their problematic relations with the locals. This issue has indeed moved through the ages, even though now it takes more humane forms than armed conflicts. Haskins presents a description of medieval students' behavior based on the records of Paris preachers: "They are so litigious and quarrelsome that there is no peace with them; wherever they go, be it Paris or Orleans, they disturb the country, their associates, even the whole university." Many of them go about the streets armed, attacking the citizens, breaking into houses, and abusing women. They quarrel among themselves over dogs, women, or what-not, slashing off one another's fingers with their swords, or, with only knives in their hands and nothing to protect their tonsured pates, rush into conflicts from which armed knights would hold back. Their compatriots come to their aid, and soon whole nations of 
students may be involved in the fray." (Haskins, 1957, p. 62) Certain restrictions were imposed on students in regard of arms possession and patterns of behavior to make them more of a student than a gambler: "Students must not carry arms, and only those who frequent the schools regularly are to enjoy the exemptions of students, the interpretation in practice being attendance at not less than two lectures a week." (Haskins, 1957, p. 16)

This paper suggests that ethical issues and behaviour of students and professors in the Middle Ages as well as today depend on the culture and traditions of the time and have a substantial ground in the social setting and, more importantly, economic conditions. Armed students running through the city was in many cases a response to the hostility of the local population. Also, the material conditions of students play a key role in transferring economic problems into social sphere, i.e. on the streets. A survey of medical workers in Britain conducted in 2001 has shown that the social characteristics of prostitutes have changed drastically for the last three or four years as a result of female students who cover their studies in higher education institutions by working as prostitutes. This is a direct consequence of increasing fees in universities in the UK. Since many students are forced to take educational loans from the banks, they prefer to involve in prostitution after classes. This situation went so far that now in Lids, for instance, sixty percent of all prostitutes are college students (Newsru, 2001). British newspaper News of the World reports that an 18-year-old British female student Rosie Reid from Bristol University has sold her virginity from the auction for 8,400 pounds: "She put her virginity up for scale, first through auction site eBay and then through her own website." (News of the World, 2004) Miss Reid told that she received 2000 propositions of which she choose 5. After personal meeting with each of the five candidates she finally announced 44 year old engineer from British 
Telecom winner of the auction. Miss Reid thinks that despite that night was horrible, it is better to be a prostitute than graduate with the debt of 15,000 pounds (Newsru, 2004).

In medieval universities, discipline and conduct was a subject of control through the multiple oaths. Rashdall writes:

Another characteristic feature of medieval life, vividly illustrated by the history of the universities, is the inordinate multiplication of oaths. The tremendous penalties involved by perjury supplied so convenient a sanction for all kinds of rules and regulations that their aid was invoked on the most trifling occasions. Modern common sense would naturally suggest that, when attendance at lectures was required, such attendance should be secured by calling over the names; in the Middle Ages the natural thing seemed to be to compel the supplicant for a degree to swear that he had attended the lectures. When a regulation was made, it was almost the invariable practice to require the persons affected to swear that they would observe it or that they had observed it. The candidate for an examination had to swear that he would not offer a bribe to the examiner; the examiner had to swear that he would not receive one. The candidate had, moreover, in some universities to swear not to wreak his vengeance by knife or dagger upon a 'ploughing' examiner. The authority of every officer was enforced by an oath of obedience. The graduate was sworn in detail not to do almost all the things that previous university legislation had forbidden. College servants, like the retainers of great households, were sworn to obey their masters. In earlier university legislation nearly every prohibition was made under penalty of excommunication or at least of incurring the guilt of perjury. It is instructive to observe in later statutes and ordinances a growing disposition to substitute written certificates for corporal oaths, and pecuniary penalties for spiritual terrors. It was 
found that practically a fine of half a crown was more deterrent than the most tremendous denunciations of posthumous vengeance, or of spiritual penalties in this life which depended for their enforcement upon the scrupulosity of the penitent and the severity of the penitentiary of the confessor (Rashdall, 1936 (c), pp. 437-438).

Nevertheless, the code of conduct may become a key document in higher education institutions of the FSU as it is in all US universities. Honor Code for students and Code of Conduct for instructors are fundamental documents. Even though it may be ineffective, it will at least state what is right and what is wrong, what is considered as misconduct and what are the penalties, and how students and professors are expected to behave in order to promote and maintain intellectual integrity in academic communities.

Rashdall describes ineffectiveness of attempts by the university administration to employ superstition and religious beliefs in imposing codes of conduct:

Yet the closed jucstaposition of superstition and the grossest irreverence is a rather startling feature of medieval student-life. When we are shocked at some of the secular things that medievals did in the most material sense the dwelling-place of Deity, the superstition may sometimes perhaps be with us as much as with them. But it is strange to find that it should have been necessary for William of Wykeham to forbid dancing in his college chapel. And it is difficult to believe that, in the century that witnessed the final triumph of the dogma of transubstantiation, it should have been necessary to denounce excommunication against students who played dice upon the very altars of Notre Dame de Paris by way of giving a finish to the dancing and singing processions in the public streets with which the feast of a nation used to be celebrated (Rashdall, 1936 (c), p. 439). 
Administrative measures to prevent corruption are often ineffective because they are not based on understanding of the nature of corruption. Attempts to interrupt with the developed traditions often lead to negative results. Good example for that may be a tradition of having banquet after the doctoral defense that exists in many universities in the FSU. In Donetsk State University, banquet after the defense of a doctoral dissertation was prohibited within the limits of the university building, including even the dining facilities. This decision had a negative impact on all participants. The candidate has to search for a restaurant within the walking distance from the University in order to organize the banquet. The University is located in the downtown, and so all the restaurants in the area are expensive. Moreover, these restaurants are aware of the situation and raise the prices for the special events. Faculty members who participate in the procedure of the defense - normally about twenty to twenty five people - have to walk from the university building to the place where the banquet is held. Such ignorance of the tradition is unjustifiable and does not represent a solution for the problem of corruption.

\section{Collective action}

Experience of the medieval universities run by the students is very interesting in terms of their control over the townsmen - suppliers of their housing, food, cloth, and other products, and professors. Collective action was used by the students as a weapon in the struggle for their rights and now presents a certain interest for many countries, including the process of unionization of graduate students in the US, student unions and student self-governance in Europe, and spontaneous collective actions of protest staged time to time by students in the FSU. According to Haskins (1958), student universities represented an organized form of protection of 
students and their interests by themselves. This priority of students as consumers is described by Haskins as follows:

The students of Bologna organized such a university first as a means of protection against townspeople, for the price of rooms and necessaries rose rapidly with the crowd of new tenants and consumers, and the individual student was helpless against such profiteering. United, the students could bring the town to terms by the threat of departure as a body, secession, for the university, having no buildings, was free to move, and there are many historic examples of such migrations. Better rent one's rooms for less than not rent them at all, and so the student organizations secured the power to fix the prices of lodgings and books through their representatives (Haskins, 1957, p. 9).

While in the FSU universities provide undergraduate and graduate students, and in many instances even professors, with dormitory accommodations, in the US college students and visiting professors are customers of the local landlords. Entire areas that surround universities make their business from renting all types of apartments, from modern to substandard and dilapidating. The rates are high and supply of living space is normally insufficient. Colleges and universities do not have control over landlords. Moreover, universities monopolize the right to accommodate undergraduate students in dormitories and collect from them unreasonably high housing fee. Graduate students are forced to search for all types of cheap pre-industrial housing. In this sense universities in the US are nowhere near fulfilling their obligations in accommodating students. Foreign students do not have any priority in being accommodated in college dormitories.

As we have mentioned before, students in the FSU are now trying to put professors under control through the actions of the university administration in order to have high quality lectures, 
seminars, and updated teaching materials. Haskins describes student demands to their professors in Italian universities:

Victorious over the townsmen, the students turned on "their other enemies, the professors." Here the threat was a collective boycott, and as the masters lived at first wholly from the fees of their pupils, this threat was equally effective. The professor was put under bond to live up to a minute set of regulations which guaranteed his students the worth of the money paid by each. We read in the earliest statutes (1317) that a professor might not be absent without leave, even a single day, and if he desired to leave town he had to make a deposit to ensure his return. If he failed to secure an audience of five for a regular lecture, he was fined as if absent - a poor lecture indeed which could not secure five hearers! He must begin with the bell and quit within one minute after the next bell. He was not allowed to skip a chapter in his commentary, or postpone a difficulty to the end of the hour, and he was obliged to cover ground systematically, so much in each specific term of the year. No one might spend the whole year on introduction and bibliography! Coercion of this sort presupposes an effective organization of the student body, and we hear of two and even four universities of students, each composed of "nations" and presided over by a rector. Emphatically Bologna was a student university, and Italian students are still quite apt to demand a voice in university affairs (Haskins, 1957, pp. 9-10).

Students in the FSU are less organized as compared to the corrupt faculty and administration. However, in many higher education institutions, both public and private, students become organized in order to oppose bribery. Often groups of students go to Dean's office to complain about the professor's extortion of bribes. This becomes quite common, but does not 
necessarily lead to the adequate reaction from the Dean's office, especially if the office itself is corrupt. Nevertheless, students exercise their power. Those in for-tuition programs pay their money and are major contributors to the university revenue. Students in private universities are especially powerful in this sense.

Faculty members and the administration have the position power. Professors execute their formal authority by assigning the grades and the administration maintains and controls educational process. Faculty members also have special knowledge, information, and expertise. Control of rewards to the students is also a faculty prerogative. The university administration controls rewards to the faculty. Bribes may be considered as rewards given to the faculty and the administration by the students.

All the parties have coercive power. Faculty members can assign low grades to students, both according to the college rules or subjectively, based on their discretion; the college administrators may create obstacles for the faculty promotions; and students can protest unfavorable actions. Faculty, administration, and students participate in alliances and networks and have access to the process of decision making. Corrupt faculty and administration may present the issue of corruption as non-existing in their higher education institution and advise students to keep quiet in order to avoid negative rumors about the department or the university overall. Many faculty members are individuals with charisma, energy and stamina, strong political skills, good verbal abilities, the capacity to articulate their visions and made points. It is more difficult for the students to demonstrate these characteristics and articulate their vision. Corruption is an influential power. 


\section{CONCLUSION}

In conclusion we would like to highlight five major points. First, there were four frames utilized in investigating legacies of the medieval universities. The first frame, that was initially intended to be a major one, is constructed based on a perception of what is considered as corruption in modern universities of the FSU, i.e. post-soviet institutions of higher education. The second frame consists of what was considered as corruption in the medieval universities. By using the second frame we identified some aspects of corruption in modern universities that would not be regarded as corrupt otherwise. The third frame that naturally emerged from the first one is based on the characteristics of the soviet-time universities. It is important to distinct these two frames, because principles on which the Soviet system of higher education was built and functioned are quite different from the ones essential for the post-soviet universities, even though legacies in this case are very strong. The fourth frame is built based on the realities of the modern US universities. This last frame did not shape well based on the fact that often the comparisons of US universities with their medieval ancestors were influenced by the perceptions of the soviet-time higher education. Another weak side of this frame is that universities in the US have a long history that sometimes goes deep into centuries--Harvard College was founded in 1636--but this important part was ignored.

Second, corrupt practices in the process of learning and conferring the degrees in both the US and the FSU universities are a legacy of the medieval university. Major distinction, however, is that in the FSU abuse takes place within the existing frame of rules. It is implicit to the system. Abuse of a university name and prestige and the state guarantee of the quality of the university degrees occur with the sale of the degree by the university officials. In the US, abuse takes 
outside of the existing frame of accredited higher education institutions. It is explicit to the system. Abuse of the college degrees occurs through the sale of the certificates by the university. Third, question of whether a certain form of financing of higher education is corrupt or not always depends on the context in which higher education institutions function. In the medieval universities, students paid entrance fees and lecture fees, some of them worked for professors, and few had partial or full scholarships. There were two essential features: 1) financial survival of the university was always an issue; and 2) professors were private tutors, affiliated with the universities. Professors had to build their reputation and attract students to their lectures. Higher education degree did not have a significant social meaning. In US universities, students pay for education. Financial survival is still a primary issue for the majority of higher education institutions. Access to higher education is limited based on the ability to pay. Inequality in opportunity is widely present. In distinction from the Medieval Europe, education in the US does have significant social meaning. The society suffers from the fact that access to higher education is based primarily on wealth rather than on academic promise. Consequently, the overall social welfare is diminished and the system may be regarded as corrupt in its nature. This form of legalized corruption comes from medieval universities.

In the Soviet system, access to higher education was loosely limited and based on academic promise rather than wealth. The system was socially effective in its nature, but at the same time it was corrupt on the functional level. Abuse of the principles of equal opportunity in admission, instruction, and graduation were indications of corruption. These forms of illegal and informal corruption were also legacies of the medieval university. Post-soviet higher education is represented by both public and private institutions. Corruption of two types is present: corruption in function and corruption in nature. First, there is a continuing abuse of functions of selection, 
training, evaluation, and graduation. Second, private educational institutions increase access to higher education based on applicants' wealth rather than academic promise. Hence, functions of selection and evaluation are often abused in lieu of the revenues. As the result, legalized and illegal, formal and informal corruption merges.

Fourth, ethics and code of conduct for students and faculty were always on a forefront of university life. Ethical issues and behaviour of students and professors in medieval universities as well as today are not only a matter of the culture and traditions of the time, but have a substantial ground in the social setting and, more importantly, economic conditions. Material conditions of students play a key role in transferring economic problems into social sphere and classrooms. Even though broadly used practice of swearing and giving multiple oaths in the medieval universities was ineffective, introduction of the honor code for students and the code of conduct for faculty members may have some positive effect on the adjustment of student and professor conduct and tackling corruption. Administrative measures to prevent corruption are often ineffective because they are not based on understanding of the nature of corruption and its cultural aspects.

Fifth, experience of medieval universities run by students is very interesting in terms of their control over the townsmen-suppliers of their housing, food, closing, and other products, and professors. Collective action was used by the students as a weapon in struggling for their rights and is now presenting certain interest in many countries, including process of unionization of graduate students in the US, student unions in Europe, and spontaneous protests by students in the FSU. Students in the FSU are now trying to put professors under control through the actions undertaken by the university administration, in order to receive high quality lecture time, vivid seminars, and updated teaching materials. Students in the FSU are less organized as compared to 
the corrupt faculty and administration. However, in many higher education institutions students tend to organize in order to oppose bribery, extortions, and other forms of corruption. Students execute their power of stakeholders and consumers. Students in the for-tuition programs pay their money and are major contributors to the university revenue. Students in the private universities are especially powerful in this sense. Students in the top schools are substantial part of academic process. This student power over the faculty members and administration creates fundamental duality in use and misuse of this power. On the one hand, students can demand higher quality of instruction and prioritize their rights, but on the other hand, students can abuse their power in demanding grades rather than knowledge and degrees rather than prestige.

In the medieval universities, professors, because of their clerical status and obligation of celibacy, did not or at least were not supposed to have children, and hence any preferences in student admission and funding, based on family relationship, were virtually absent. Professors were not parents and did not have an incentive to advance their children to the universities where they taught for the simple reason of absence of the latter. In countries where access to higher education and governmental funding is limited, faculty members are always in search of favourable decisions of admission and funding for their children, grandchildren, nephews, nieces, and other close relatives. This phenomenon, known as nepotism, is a rampant practice in the FSU that transforms public and private universities into "family enterprises." There is no doubt that nepotism in this case is one of the major forms of corruption.

To underline all the points listed above, we will summarize by saying that universities in the US are in many ways a visual legacy of medieval universities. Decentralized higher education in the US is a well-developed industry. This industry is based on the market principles and is driven by both individual demands for education and rates of return on investment in 
education. Corruption in this industry is either linked to the public policy, or common to other forms of corruption in the corporate America, or otherwise is not regarded as such.

Soviet universities, unified in the centralized system of higher education and tightly controlled by hierarchical structures of the government, were nevertheless in many ways direct descendants of medieval universities. Corruption in the post-soviet universities is often a legacy of their medieval ancestors. Universities in the FSU inherited some essential features of medieval universities. In general, universities in the US and in the FSU acquired some forms of corruption as legacies of the medieval university, even though these forms may appear to be different. The differences in approaches to corruption as well as the differences between the systems are rather vague, but still significant enough to be identified. 


\section{References}

Berg, L., Hahn, H., \& Schmidhauser, J. (1976). Corruption in the American Political System. Morristown, NJ: General Learning Press.

Birnbaum, R. (1988). How Colleges Work: The Cybernetics of Academic Organization and Leadership. San Francisco, CA: Jossey Bass.

Brender, A. (2004). Head of Japanese University Faces Charges of Defrauding Government. The Chronicle of Higher Education, September 13.

Britanka Prodala Devstvennost' s Aukciona za 8,400 funtov [British Woman Sold Her Virginity on the Auction for 400 British Pounds]. Newsru. March 2004. Retrieved March 30, 2004 from www.newsru.com/world/21mar2004/prost.html

Britanskie Studentki Oplachivaut Uchebu, Zanimayas' Prostituciey [British Students Pay for Their Study by Working as Prostitutes]. Newsru, April 2004. Retrieved April 30, 2004 from www.newsru.com/world/30apr2001/britishprostitutes.html

Brockliss, L., Denley, P., \& Schmitt, C. (1981). History of Universities, Vol. I. London: Avebury.

Compayre, G. (1893). Abelard and the Origin and Early History of Universities. New York: Charles Scribner's Sons.

DW-WORLD: 35 professorov universiteta Gamburga vystupili protiv prisvoeniya Putinu zvaniya pochetnogo doctora [DW-WORLD: 35 professors of the University of Hamburg Voted Against Conferring an Honorary Doctorate to Putin]. Retrieved July 19, 2004 from www.newsru.com/world/19jul2004/hamburg.html 
Garvardskiy universitet podal isk protiv "Surgutneftegaza" [Harvard University has Initiated a Lawsuit against "Surgutneftegaz"]. Retrieved June 30, 2004 from www.newsru.com/30jun2004.html

Guriev, S. (2004). Red Tape and Corruption. Journal of Development Economics, 73(2), pp. 489504.

Haskins, C. (1957). The Rise of The Universities. London: Cornell University Press.

Hill, C. (1972). The Radical Critics of Oxford and Cambridge in the 1650s. In J. Baldwin and R. Goldthwaite (Eds.). Universities in Politics: case Studies from the Late Middle Ages and Early Modern Period. Baltimore, MD: The Johns Hopkins Press.

Honorary Doctors 2000. University of Oslo. Retrieved March 30, 2004 from http://www.uio.no/english/about_uio/honorary-doctors/2000/

Hyde, J. (1972). Commune, University, and Society in Early Medieval Bologna. In J. Baldwin and R. Goldthwaite (Eds.). Universities in Politics: case Studies from the Late Middle Ages and Early Modern Period. Baltimore, MD: The Johns Hopkins Press.

I Sold Virginity to Dad Aged 44. News of the World. Retrieved March 21, 2004, from www.newsoftheworld.co.uk/story_pages/news2.shtml

Johnston, M. (1982). Political Corruption and Public Policy in America. Belmont, CA: Brooks/Cole Publishing Co.

Johnston, M. (1986). Right and Wrong in American Politics: Popular Concepts of Corruption. Polity, 18(3), pp. 367-391.

Kaminsky, H. (1972). The University of Prague in the Hussite Revolution: the Role of the Masters. In J. Baldwin and R. Goldthwaite (Eds.). Universities in Politics: case Studies 
from the Late Middle Ages and Early Modern Period. Baltimore, MD: The Johns Hopkins Press.

Keller, M. (1978). Corruption in America: Continuity and Change. In A. Eisenstadt, A. Hoogenboom, and H. Trefousse. Before Watergate: Problems of Corruption in American Society. Brooklyn, NY: Brooklyn College Press.

Key, V. (1936). The Techniques of Political Graft in the United States. Chicago, IL: The University of Chicago Libraries.

Kibre, P. (1948). The Nations in The Mediaeval Universities. Cambridge, MA: Mediaeval Academy of America.

Kigotho, W. (2004). Nigerian University Revokes Thousands of Diplomas in Crackdown on Academic Fraud. The Chronicle of Higher Education, November 1.

Lasswell, H., \& Rogow, A. (1963). Corruption, Power, and Rectitude. Englewood Cliffs, NJ: Prentice Hall.

Maieru, A. (1993). University Training in Medieval Europe. New York: Brill.

Meeting at Moscow State Institute of International Relations. AzerTAg, Baku, 2004. Retrieved January $\quad$ 2005, $\quad$ from $\quad$ http://www.ilhamaliyev.org/s07_meetings/_meeting_e.html?meeting_16_e.html

Niyazov Receives Honorary Doctorate from Malta University. The Times of Central Asia, Retrieved October 26, 2004 from http://www.times.kg/?c=5\&d=112\&dt=2004-01-05

Noonan, J. (1983). Bribery. In Encyclopedia of Crime and Justice. New York, NY: McMillan and Free Press.

Nye, J. (1967). Corruption and Political Development: a Cost-Benefit Analysis. American Political Science Review, 61(2), pp. 417-427. 
Payne, P. (1975). The Corrupt Society: From Ancient Greece to Present-Day America. New York: Praeger Publishers.

Peters, J., \& Welch, S. (1978). Political Corruption in America: A Search for Definitions and a Theory, or If Political Corruption is in the Mainstream of American Politics, Why Is It not in a Mainstream of American Politics Research? American Political Science Review, 72(3), pp. 974-984.

Piltz, A. (1981). The World of Medieval Learning. Basil: Blackwell.

Pochesni Profesory ta Doktory NaUKMA [Honorary Professors and Doctors of the National University Kiev-Mohyla Academy]. Retrieved January 1, 2005 from http://www.ukma.kiev.ua/ua/general/pochesni/index.php

Putin stanet pochetnym docotrom Gamburgskogo universiteta s bolshim trudom [Putin will Become an Honorary Doctor of the University of Hamburg with Big Difficulty]. Retrieved July 20, 2004 from www.newsru.com/world/20jul2004/hardly.html

Rait, R. (1931). Life in the Medieval University. Cambridge: Cambridge University Press.

Rashdall, H. (1936). The Universities of Europe in the Middle Ages: Salerno, Bologna, Paris. Vol. I. In B. Emden and M. Powicke (Eds.). The Universities of Europe in the Middle Ages. Oxford: Clarendon Press.

Rashdall, H. (1936). The Universities of Europe in the Middle Ages: Italy, Spain, France, Germany, Scotland, etc. Vol. II. In B. Emden and M. Powicke (Eds.). The Universities of Europe in the Middle Ages. Oxford: Clarendon Press.

Rashdall, H. (1936). The Universities of Europe in the Middle Ages: English Universities Student Life. Vol. III. In B. Emden and M. Powicke (Eds.). The Universities of Europe in the Middle Ages. Oxford: Clarendon Press. 
Rose-Ackerman, S. (1974). The Economics of Corruption. Philadelphia, PA: Pennsylvania University, Fels Discussion Paper \#53.

Rose-Ackerman, S. (1978). Corruption: A Study in Political Economy. New York, NY: Academic Press.

Rose-Ackerman, S. (1999). Corruption and Government: Causes, Consequences, and Reform. New York: Cambridge University Press.

Sadovnichiy, V. (2001). O reforme i korrupcii v vysshem obrazovanii [About the Reform and Corruption in Higher Education]. NTV, 2001. Retrieved October 3, 2001, from www.ntvru.com/russia/03Oct2001/sadovnichiy_bribe.html

Sud Nyu-Yorka priostanovil process, nachaty Garvardom protiv "Surgutneftegaza" [The Court of New-York Postponed the Lawsuit Initiated by Harvard Against “Surgutneftegaz”]. Retrieved July 30, 2004 from www.newsru.com/world/30jul2004/ussa.html

Thelin, J. (1982). Higher Education and Its Useful Past. Cambridge, MA: Schenkman Publishing Company.

V Rossii v 2003 godu roditeli za obrazovanie detey dali vziatok na 26,5 milliarda rubley [In Russia in 2003 Parents Paid 26.5 Billion Rubles in Bribes for Their Children's $\begin{array}{lllll}\text { Education]. } & \text { Retrieved } & \text { June } & 24, & 2004\end{array}$ www.newsru.com/russia/24jun2004/vzytki.html

Verger, J. (1972). The University of Paris at the End of the Hundred Years' War. In J. Baldwin and R. Goldthwaite (Eds.). Universities in Politics: case Studies from the Late Middle Ages and Early Modern Period. Baltimore, MD: The Johns Hopkins Press. 
Verger, J. (2000). The First French Universities and the Institutionalization of Learning: Faculties, Curricula, Degrees. In J. Engen (Ed.). Learning Institutionalized: Teaching in the Medieval University. Notre Dame, IN: University of Notre Dame Press. 